\title{
PRODUTOS DE EMULSÃO (FIAMBRES) ELABORADOS COM CARNE DE POEDEIRAS LEVES (LEGHORN) DE DESCARTE E ÓLEOS VEGETAIS
}

\author{
TANIA REgINA FIORE NARDIN \\ Economista Doméstica
}

Orientador: Prof. Dr. MURILO GRANER

Dissertação apresentada à Escola Superior de Agricultura "Luiz de Queiroz", Universidade de São Paulo, para obtenção do título de Mestre em Ciências, Área de Concentração: Ciência e Tecnologia de Alimentos.

P I R A C I C A B A

Estado de São Paulo - Brasil

Dezembro - 1997 
Dados Internacionais de Catalogação na Publicação (CIP) DIVISÃO DE BIBLIOTECA E DOCUMENTAÇĀO - Campus "Luiz de Queiroz"/USP

Nardin, Tania Regina Fiore

Produtos de emulsão (fiambres) elaborados com carne de poedeiras leves

(Leghorn) de descarte e óleos vegetais / Tania Regina Fiore Nardin. - - Piracicaba, 1997.

62 p. : il.

Dissertação (mestrado) - - Escola Superior de Agricultura Luiz de Queiroz, 1997. Bibliografia.

1. Carne de ave (emulsão) 2. Fiambre 3. Galinha poedeira (descarte) 4. Óleo vegetal l. Título

CDD 664.93 


\section{PRODUTOS DE EMULSÃO (FIAMBRES) ELABORADOS}

COM CARNE DE POEDEIRAS LEVES (LEGHORN) DE DESCARTE E ÓleOS VEGETAIS

TANIA Regina FIORE NARDIN

Aprovada em: 04.03.1998

Comissão julgadora:

Prof. Dr. Murilo Graner

Prof ${ }^{\mathrm{e}}$. Dr. Marilia Oetterer

Prof $^{\mathrm{a}}$. Dr ${ }^{\mathrm{a}}$ Rachel Elisabeth Domarco
ESALQ/USP

ESALQ/USP

CENA/USP

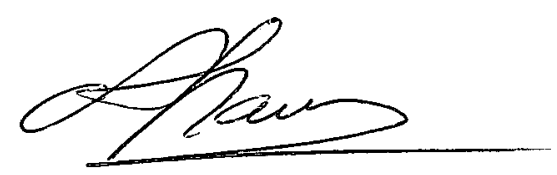

Prof. Dr. MURILO GRANER

Orientador 
Ao meu esposo

e meus filhos,

com carinho

DEDICO 


\section{AGRADECIMENTOS}

- Ao Prof. Dr. Murilo Graner pela orientação científica, apoio, incentivo e dedicação prestados no decorrer de toda a pesquisa.

- À Escola Superior de Agricultura "Luiz de Queiroz", em especial ao Departamento de Ciência e Tecnologia Agroindustrial pela disponibilidade do uso de equipamentos e drogas.

- À Granja Saito S. A. e ao Matadouro Avícola Flamboiã Ltda., pelo fornecimento da matéria-prima.

- À Marta Regina Verruma Bernardi e Marta Helena Fillet Spoto, pela orientação na coordenação das análises sensoriais.

- Aos provadores, pela participação nas análises sensoriais.

- Ao Prof. Dr. Carlos Tadeu S. Dias, pela assessoria na análise estatística.

- Aos Técnicos José Carlos T. Mendes e Ivani A. M. Moreno pela colaboração durante a fase experimental.

- À Bibliotecária Beatriz H. Giongo, pela auxilio e organização das referências bibliográficas.

- E a todos os que, direta ou indiretamente, contribuíram para a realização deste trabalho. 


\section{SUMÁRIO}

Página

LISTA DE FIGURAS........................................................................... VIII

LISTA DE TABELAS............................................................................. X

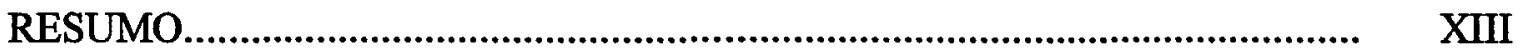

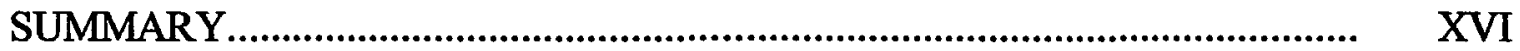

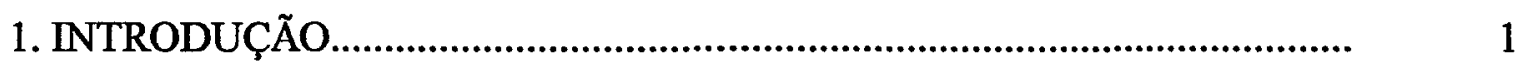

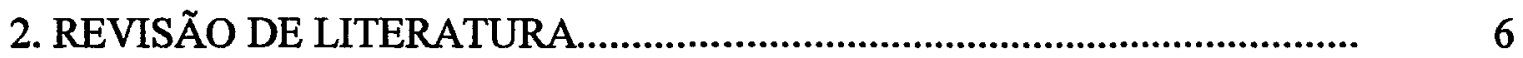

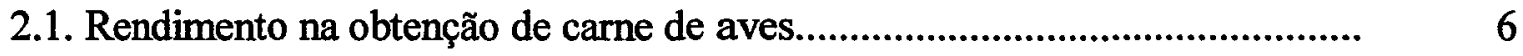

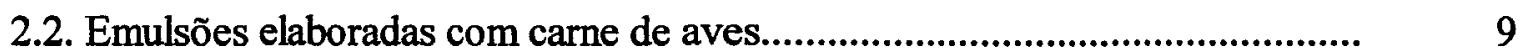

2.3. Emulsões elaboradas com óleos vegetais................................................... 12

2.4. Fiambres elaborados com carne de frango.................................................. 17

3. MATERIAL E MÉTODOS........................................................................ 21

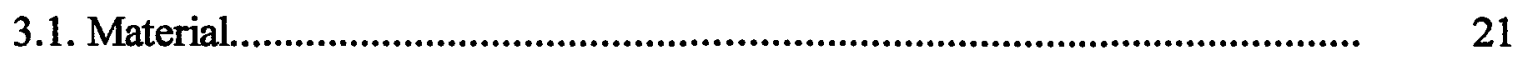

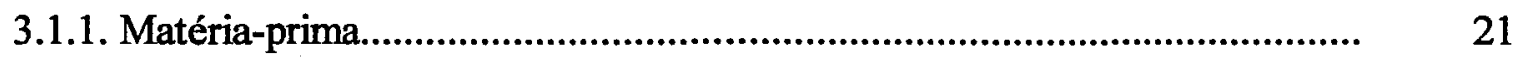

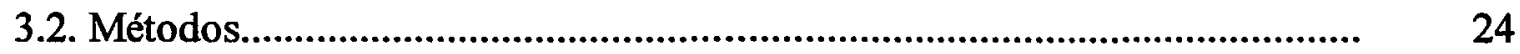

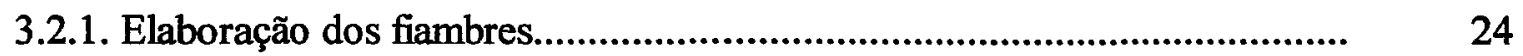

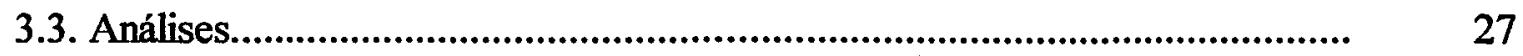




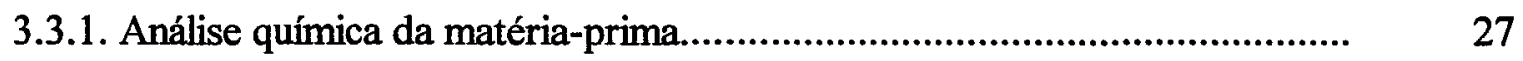

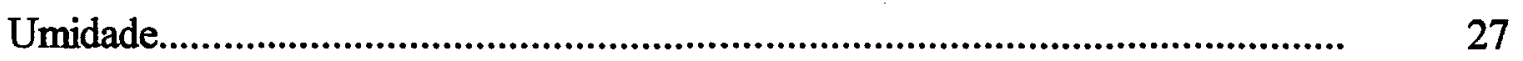

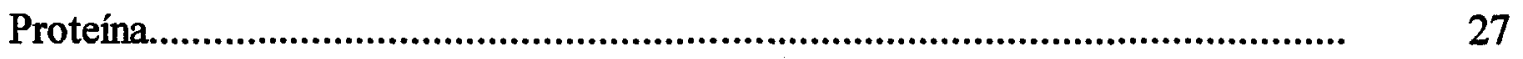

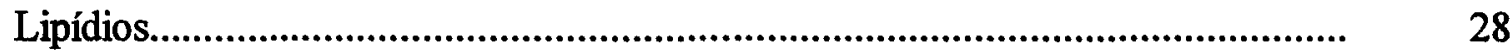

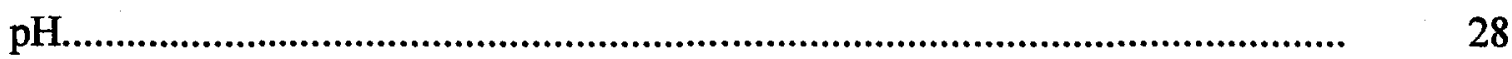

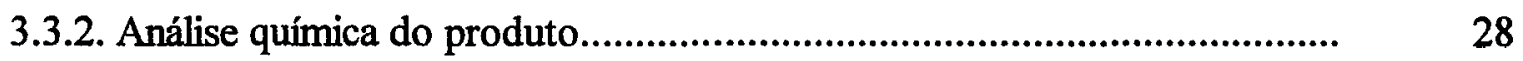

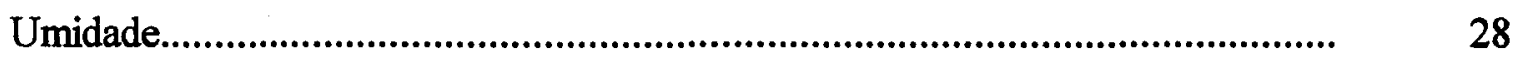

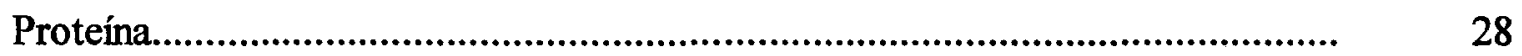

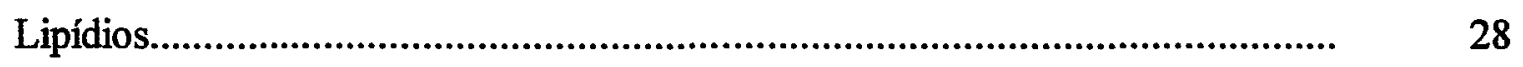

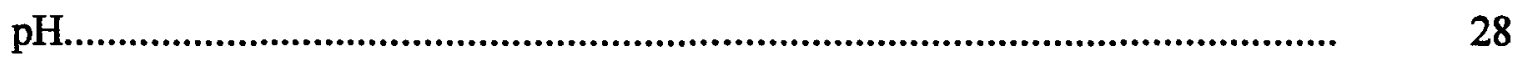

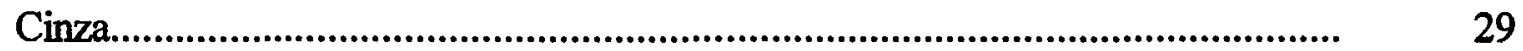

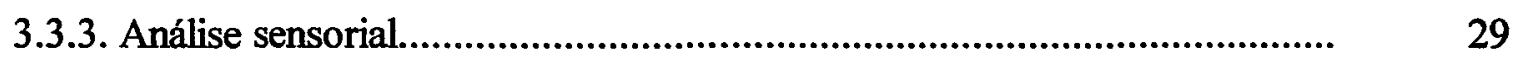

3.3.4. Análise estatística.......................................................................... 30

4. RESULTADOS E DISCUSSÃO................................................................

4.1. Rendimento na desossa manual........................................................... 31

4.2. Composição química da matéria-prima..................................................... 33

4.3. Rendimentos na elaboração do produto....................................................... 34

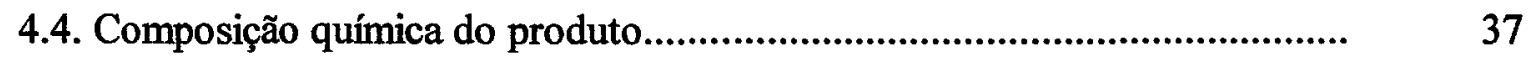

4.5. Qualidade sensorial dos produtos............................................................... 39

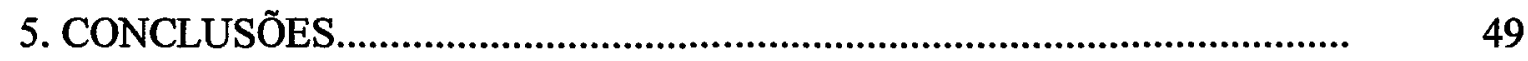

REFERÊNCIAS BIBLIOGRÁFICAS....................................................... 50

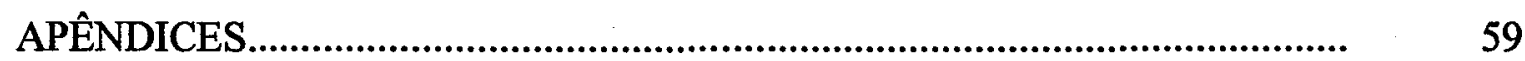




\section{LISTA DE FIGURAS}

Página

1 Fluxograma da obtenção da matéria-prima cárnea...........................................

2 Fluxograma do processamento na elaboração de fiambres de poedeiras e

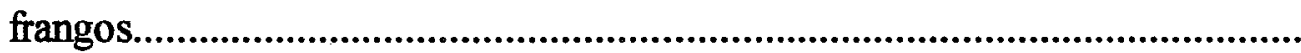

3 Avaliação sensorial dos fiambres elaborados a partir de carne de poedeira e óleos vegetais.

4 Avaliação sensorial, quanto ao sabor, dos fiambres elaborados a partir de carne de poedeira e de frango com óleo de soja e milho.

5 Avaliação sensorial, quanto à maciez, dos fiambres elaborados a partir de carne de poedeira e de frango com óleo de soja e milho 
6 Avaliação sensorial, quanto à suculência, dos fiambres elaborados a partir de carne de poedeira e de frango com óleo de soja e milho.

7 Avaliação sensorial, quanto à cor, dos fiambres elaborados

a partir de carne de poedeira e de frango com óleo de soja e milho..................

8 Avaliação sensorial, quanto à qualidade global, dos fiambres elaborados a partir de carne de poedeira e de frango com óleo de soja e milho 46

9 Fiambres de carne de poedeiras elaborados com óleo de soja (1), óleo de milho (2), óleo de girassol (3) e óleo de canola (4) (Etapa I)...................

10 Fiambres de carne de poedeiras elaborados com óleo de soja (1) e óleo de milho (2) e fiambres de carne de frangos elaborados com óleo de soja (3) e óleo de milho (4) (Etapa II)............................................. 


\section{LISTA DE TABELAS}

Página

1 Produção mundial de carne de aves

2 Consumo per capita de carne de frango no Brasil (1992-96).

3 Maiores estados produtores de pintos de corte e produção regional participação percentual - 1981 a 1985.

4 Média mensal do plantel de poedeiras no Brasil

5 Rendimento em carcaça, partes, desossa e gordura abdominal em relação ao peso vivo, aos 45 dias de idade.

6 Teor de proteína solúvel em solução salina e capacidade de emulsionar gordura desta proteina em carnes de frango ("broiler") e de galinha leve.......

7 Ingredientes não cárneos e aditivos utilizados na elaboração dos fiambres (em relação aos ingredientes cárneos e óleo). 
16 Avaliação sensorial, quanto ao sabor, dos fiambres elaborados a partir de carne de poedeira e de frango com óleo de soja e milho............................

17 Avaliação sensorial, quanto à maciez, dos fiambres elaborados a partir de carne de poedeira e de frango com óleo de soja e milho.............................

18 Avaliação sensorial, quanto à suculência, dos fiambres elaborados a partir de carne de poedeira e de frango com óleo de soja e milho

19 Avaliação sensorial, quanto à cor, dos fiambres elaborados a partir de carne de poedeira e de frango com óleo de soja e milho

20 Avaliação sensorial, quanto à qualidade global, dos fiambres elaborados a partir de carne de poedeira e de frango com óleo de soja e milho. 


\title{
PRODUTOS DE EMULSÃO (FIAMBRES) ELABORADOS COM
}

CARNE DE POEDEIRAS LEVES (LEGHORN) DE DESCARTE E ÓLEOS VEGETAIS

\author{
Autora: TANIA REGINA FIORE NARDIN
}

Orientador: Prof. Dr. MURILO GRANER

\section{RESUMO}

A aceitação e o custo da carne de poedeiras leves, descartadas da postura por motivo de ordem econômica, são relativamente pequenos. Entretanto, a sua utilização como matéria-prima na elaboração de certos produtos cárneos pode levar a um melhor aproveitamento da mesma. 
Foram elaborados fiambres (emulsões) curados e defumados com carne de poedeiras leves e diferentes óleos vegetais, que foram comparados com produto semelhante, obtido com a carne de frangos de corte.

Foram adquiridas 30 carcaças de poedeiras (congeladas), obtendo-se, após descongelamento por 48 horas, carne mista (de peito, pernas e coxas e coxinhas das asas, em proporção natural) através de desossa manual, mistura e moagem. A carne mista foi mantida congelada até o momento de sua utilização.

Na desossa manual dos cortes, obteve-se um rendimento médio de $14,73 \%$ para peito, $14,91 \%$ para pernas e coxas e $2,46 \%$ para as coxinhas das asas, em relação ao peso da carcaça (média de $1195,81 \mathrm{~g}$ ). A carne mista foi obtida a partir de $14,73 \%$ de carne branca (peito) e $17,37 \%$ de carne escura (pernas e coxas e coxinhas das asas).

Na Etapa I elaboraram-se fiambres a partir de carne de poedeiras com diferentes óleos vegetais (soja, milho, girassol e canola), a nível de $12,5 \%$. Os produtos não diferiram significativamente entre si, mas houve uma tendência, quanto a aceitabilidade, pelos produtos elaborados com óleo de milho e de canola. Os fiambres apresentaram, em média, $64,76 \%$ de umidade, $13,91 \%$ de proteína, $16,62 \%$ de lipídios, $3,00 \%$ de cinza, $\mathrm{pH} 6,21$ e rendimento de $94,96 \%$ no processamento térmico e resfriamento.

Na Etapa II desenvolveram-se fiambres com carne de poedeira e de frango (controle), utilizando-se óleo de soja e óleo de milho.

Quanto ao sabor os produtos elaborados com carne de poedeira e óleo de soja foram superiores ao produto controle e não houve diferença significativa quando elaborados com óleo de milho. Apresentaram-se mais macios os elaborados com carne de 
frango e óleo de soja, em relação à carne de galinha. Para a avaliação da suculência, não ocorreram diferenças significativas. A cor dos fiambres elaborados com carne de poedeira foi mais atrativa que a dos produtos elaborados com carne de frango. Quanto à qualidade global os fiambres elaborados com carne de poedeira e óleo de soja foram os preferidos pelos provadores, em relação à carne de frango.

Nas condições do presente trabalho, pode-se estimar que 100kg de carcaças de poedeiras (na forma de carcaça congelada), correspondem em média a $34,34 \mathrm{~kg}$ de fiambre e que $100 \mathrm{~kg}$ de carne mista correspondem a $113,50 \mathrm{~kg}$ de produto. 


\title{
EFFECT OF LIGHT WEIGHT HEN (Leghorn) MEAT ON QUALITY OF CHICKEN LOAVES (EMULSION TYPE) PREPARED WITH VEGETABLE OILS
}

\author{
Author: TANIA REGINA FIORE NARDIN \\ Adviser: Prof. Dr. MURILO GRANER
}

\section{SUMMARY}

Cured and smoked chicken loaves (emulsion type) were prepared with light weight hen (Leghorn) meat and vegetable oils (soybean, corn, sunflower, and canola). Broiler (Hubbard Peterson) meat was also used, for comparison.

The meat of thirty frozen hen carcasses was thawed (48h in refrigerator) and hand deboned from breast, legs and wings. The meat was cut into small pieces, ground and kept frozen until emulsion preparation. 
When boning hen carcasses, average yields of $14.73 \%, 14.91 \%$, and $2.46 \%$ were found for breast, leg, and wing meat, respectively. The yield was $14.73 \%$ for light meat, and $17.37 \%$ for dark meat. Carcass weight averaged $1195.81 \mathrm{~g}$.

As an average, $34.34 \mathrm{~kg}$ of loaf were obtained from $100 \mathrm{~kg}$ of hen carcasses, and $113.5 \mathrm{~kg}$ of product were prepared from $100 \mathrm{~kg}$ of boned light and dark hen meat.

In a first trial, chicken loaves were prepared with hen meat (87.5\%) and vegetable oils (12.5\%). Soybean, corn, sunflower, and canola oils were used. No significant differences were found for acceptability of products prepared with the different oils; however, loaves with corn and canola oils had higher scores.

The final products had the following average composition: $64.76 \%$ moisture, $13.91 \%$ protein, $16.62 \%$ fat, and $3 \%$ ash; $\mathrm{pH}$ was 6.21 . Thermal processing yield averaged $94.96 \%$.

In a second trial, loaves were prepared with hen meat and soybean and corn oils, and with broiler meat and the same oils.

The flavor of chicken loaves prepared with hen meat and soybean oil was significantly better than that of products prepared with broiler meat and the same oil. No significant difference was found when products were made with corn oil.

Tenderness was favored when broiler meat and soybean oil were used, as related to hen meat. No significant differences were found for juiciness. Loaves prepared with hen meat had a better color. 
XVIII

In the overall quality evaluation, the loaves made with hen meat and soybean oil were better than products prepared with broiler meat and the same oil. 


\section{INTRODUÇÃO}

A avicultura brasileira continua crescendo fortemente, mantendo assim a tendência que vem caracterizando a última década. Segundo dados do Anuário Estatístico da Produção Animal - ANUALPEC (1996), a produção de carne de aves no período de 1986 a 1995, no Brasil, aumentou de 1,6 milhões para 4,1 milhões de toneladas. Tais volumes permitem que o Brasil ainda se posicione como o terceiro maior produtor mundial dessa carne (Tabela 1).

Tabela 1 - Produção mundial de carne de aves, em $1.000 \mathrm{t}$

\begin{tabular}{cccccc}
\hline Países & 1992 & 1993 & 1994 & $1995^{*}$ & $1996^{* *}$ \\
\hline Estados Unidos & 11.885 & 12.396 & 13.206 & 13.860 & 14.730 \\
China & 4.540 & 5.736 & 7.550 & 7.500 & 8.500 \\
Brasil & 2.932 & 3.211 & 3.491 & 3.888 & 4.495 \\
França & 1.866 & 1.875 & 1.961 & 2.020 & 2.000 \\
\hline
\end{tabular}

* Estimativa ** Previsão Fonte: Guia Aves e Ovos /Fev.96 
$\mathrm{O}$ aumento de produção permitiu que se expandisse significativamente o consumo per capita (Tabela 2), o qual foi estimulado pelas novas tecnologias industriais para produção, comercialização e distribuição de carne de frango, além de preços mais acessíveis e preferência pela carne branca de aves, considerada mais saúdavel, por ser rica em proteína e apresentar menor teor de colesterol e gordura (Oliveira, 1995).

Tabela 2 - Consumo per capita de carne de frango no Brasil (1992-96)

\begin{tabular}{cc}
\hline Ano & Frango (kg/hab/ano) \\
\hline 1992 & 16,0 \\
1993 & 17,0 \\
1994 & 18,3 \\
1995 & 23,0 \\
$1996^{*}$ & 25,0
\end{tabular}

* Estimativa $\quad$ Fonte: Guia Aves e Ovos/Fev.96

A produção brasileira está centralizada principalmente nas regiões Sul e Sudeste, sendo o Estado de São Paulo o maior produtor (Tabela 3). 
Tabela 3 - Maiores estados produtores de pintos de corte e produção regional - participação percentual - 1981 a 1995

\begin{tabular}{ccccc}
\hline UF & 1981 & 1986 & 1991 & 1995 \\
\hline São Paulo & 28,19 & 22,96 & 21,01 & 22,56 \\
Santa Catarina & 16,33 & 19,78 & 19,83 & 17,84 \\
Paraná & 9,87 & 16,06 & 16,10 & 16,53 \\
Rio Grande do Sul & 16,27 & 15,11 & 13,10 & 15,21 \\
Minas Gerais & 13,49 & 12,72 & 14,21 & 11,73 \\
Pernambuco & 4,46 & 3,97 & 4,87 & 4,83 \\
Ceará & 3,20 & 2,83 & 3,12 & 2,85 \\
Demais Estados & 8,19 & 6,57 & 7,76 & 8,45 \\
\hline Sul & 42,47 & 50,96 & 49,03 & 49,58 \\
Sudeste & 46,90 & 39,29 & 38,36 & 36,27 \\
Nordeste & 8,71 & 7,57 & 9,85 & 9,93 \\
Centro - Oeste & 0,75 & 0,93 & 1,17 & 2,53 \\
Norte & 1,17 & 1,25 & 1,60 & 1,70 \\
\hline
\end{tabular}

Fonte: APINCO - Avicultura de Corte - Brasil - 1996

A indústria avícola vem apresentando notável evolução nas práticas de industrialização. Em substituição ao comércio de frango inteiro vem se expandindo o comércio do frango refrigerado ou congelado, já recortado em partes como peito, asas, coxas, pernas ou de cortes desossados na forma de filés de peito ou de coxa, embalados em sacos plásticos, bandejas ou caixas. Também vem sendo incrementada a oferta de produtos de carnes de aves cobrindo toda a gama de produtos feitos com carnes bovinas e suínas e introduzindo-se novos produtos como os "nuggets" e outros empanados. O frango inteiro representa em média $50 \%$ da comercialização e as partes cerca de $45-47 \%$. 
Os produtos industrializados como hambúrgueres, "nuggets", almondegas e salsichas representam somente 3 a 5\% da comercialização (Beraquet,1992).

Segundo Schneider (1973), uma forma de melhor aproveitamento e, também, uma conquista de um novo e maior mercado para carne de aves, seria o uso deste produto em salsicharia, utilizando-se principalmente a carne de galos e galinhas descartadas, que não encontram consumo fácil. Lyons \& Vandepopuliere (1996) afirmam que, nos Estados Unidos da América, a maioria das galinhas (Leghorn) de descarte tem sido utilizadas em tortas ou sopas. $\mathrm{Na}$ Tabela 4 encontram-se dados do plantel de poedeiras no Brasil.

A aceitabilidade e, consequentemente, o valor comercial da carne de galinhas leves, descartadas da postura por motivo de ordem econômica, é relativamente pequeno. Tais aves apresentam pouca carne e esta não é tenra, requerendo cocção prolongada para ser consumida, em detrimento de outras propriedades organoléticas e do seu valor nutritivo. Por outro lado, a utilização de sua carne como matéria-prima na elaboração de certos produtos cárneos pode levar a um melhor aproveitamento da mesma (Breclaw \& Dawson, 1970). 
Tabela 4 - Média mensal do plantel de poedeiras no Brasil.

\begin{tabular}{ccc}
\multicolumn{3}{c}{$1986-1996$} \\
\hline Ano & Poedeiras & Índice \\
& $(1.000$ Cabeças $)$ & \\
\hline 1986 & 53.635 & 100 \\
1987 & 63.751 & 119 \\
1988 & 61.038 & 114 \\
1989 & 50.673 & 95 \\
1990 & 55.472 & 104 \\
1991 & 56.590 & 106 \\
1992 & 58.286 & 109 \\
1993 & 52.596 & 99 \\
1994 & 55.603 & 104 \\
1995 & 58.250 & 108 \\
$1996 *$ & 61.745 & 115 \\
\hline
\end{tabular}

* Previsão Fonte: Guia Aves e Ovos / Fev. 96

O presente trabalho foi realizado tendo como objetivo o aproveitamento de partes comestíveis de poedeiras leves de descarte como alternativa na obtenção de um produto de emulsão (fiambre curado e defumado), com óleos vegetais, que foi comparado com produto semelhante, obtido com a carne de frangos de corte. 


\section{REVISÃO DE LITERATURA}

\subsection{Rendimento na obtenção de carne de aves}

A qualidade da carcaça e o rendimento são dois aspectos que estão relacionados entre si e a sua separação, ao nível da indústria, é bastante complexa, haja vista que eles contribuem para o lucro ou para o prejuízo de um programa integrado (Ribeiro, 1995). Segundo este autor, vários fatores influem decisivamente no rendimento das carcaças de aves, tais como: fatores de longa duração - envolvem a criação das aves (manejo, doenças, fisiologia, nutrição, etc) e fatores de curta duração - eventos que ocorrem nas últimas 24 horas que antecedem o abate (jejum e dieta hídrica, apanha, transporte, espera na plataforma de recepção, enganchamento, insensibilização e sangria).

Graner (1987a) determinou o rendimento na obtenção de cortes e na desossa manual de partes de frango (resfriado comercial). O rendimento porcentual médio obtido nos cortes diferiu pouco para o peito e o conjunto de coxas e pernas, que totalizaram $60 \%$ do peso da carcaça. Na obtenção de carne branca (peito), o rendimento médio foi de $65 \%$ em relação ao peso do corte, e de $18 \%$ em relação ao peso da carcaça; a 
carne escura (coxas e pernas) foi obtida na proporção de $58 \%$, em relação ao peso das partes, e de $18 \%$, em relação ao peso da carcaça. As coxinhas das asas representaram em média $3 \%$ de carne em relação ao peso da carcaça.

Estudos sobre desempenho, rendimento em carcaça, cortes e desossa de três linhagens comerciais (Hubbard, Ross e Cobb) de frangos de corte foram realizados por Murakami et al. (1995). Os resultados do rendimento em carcaça e partes e porcentagem de gordura abdominal das linhagens são apresentadas na Tabela 5 . Concluiu-se que, para a carcaça, se ela for comercializada inteira com pés, cabeça e pescoço, pode-se optar por qualquer uma das linhagens estudadas. Se a comercialização for por partes, as linhagens Ross e Cobb, apresentaram melhor rendimento de peito e filé de peito; e se a opção for por coxa e perna desossadas, a melhor linhagem é a Cobb. 
Tabela 5 - Rendimento em carcaça, partes, desossa e gordura abdominal em relação ao peso vivo, aos 45 dias de idade.

\begin{tabular}{|c|c|c|c|c|c|c|}
\hline \multirow[t]{2}{*}{ Características } & \multicolumn{3}{|c|}{ Linhagem } & \multicolumn{2}{|c|}{ Sexo } & \multirow[b]{2}{*}{ CV\% } \\
\hline & Hubbard & Ross & Cobb & Macho & Fêmea & \\
\hline Peso vivo, $\mathrm{g}$ & 2283,20 & 2297,20 & 2274,20 & 2501,20 & 2068,53 & 5,43 \\
\hline Penas e sangue, $\%$ & $9,40 \mathrm{a}$ & $9,63 \mathrm{ab}$ & $9,17 \mathrm{~b}$ & $9,34 a$ & $9,46 \mathrm{a}$ & 8,44 \\
\hline Rend. de carcaça ${ }^{1}, \%$ & $68,18 b$ & $68,65 \mathrm{ab}$ & $68,82 \mathrm{a}$ & $68,72 a$ & $68,38 \mathrm{a}$ & 1,72 \\
\hline Rend. de carcaça ${ }^{2}, \%$ & $78,65 a$ & $78,60 \mathrm{a}$ & $79,02 a$ & $79,23 a$ & $78,08 b$ & 1,44 \\
\hline Pés, \% & $4,44 a$ & $4,08 b$ & $4,09 b$ & $4,53 a$ & $3,87 b$ & 7,77 \\
\hline Cabeça + pescoço, $\%$ & $6,04 a$ & $5,87 \mathrm{a}$ & $6,11 \mathrm{a}$ & $6,20 \mathrm{a}$ & $5,81 b$ & 9,23 \\
\hline Dorso, \% & $17,20 \mathrm{a}$ & $16,82 \mathrm{ab}$ & $16,66 \mathrm{~b}$ & $17,20 \mathrm{a}$ & $16,59 b$ & 6,47 \\
\hline Asa, $\%$ & $8,49 a$ & $8,24 b$ & $8,30 \mathrm{ab}$ & $8,28 b$ & $8,41 \mathrm{a}$ & 6,03 \\
\hline Peito, \% & $19,88 b$ & $20,97 \mathrm{a}$ & $20,97 a$ & $20,07 b$ & $21,14 a$ & 5,09 \\
\hline Filé, \% & $14,11 b$ & $15,27 \mathrm{a}$ & $15,45 \mathrm{a}$ & $14,61 \mathrm{~b}$ & $15,28 \mathrm{a}$ & 7,03 \\
\hline Ossos, $\%$ & $3,37 \mathrm{a}$ & $3,36 \mathrm{a}$ & $3,31 \mathrm{a}$ & $3,34 a$ & $3,35 a$ & 14,33 \\
\hline Pele, $\%$ & $2,21 \mathrm{a}$ & $2,18 \mathrm{a}$ & $2,04 a$ & $1,98 b$ & $2,32 a$ & 24,47 \\
\hline Coxa + perna, $\%$ & $22,67 a$ & $22,57 \mathrm{a}$ & $22,81 \mathrm{a}$ & $23,15 a$ & $22,22 b$ & 4,01 \\
\hline Carne + pele, $\%$ & $17,08 b$ & $17,34 b$ & $17,79 a$ & $17,62 \mathrm{a}$ & $17,19 a$ & 5,48 \\
\hline Ossos, $\%$ & $5,42 \mathrm{a}$ & $5,10 \mathrm{~b}$ & $4,94 b$ & $5,42 \mathrm{a}$ & $4,89 b$ & 7,94 \\
\hline Vísceras comestiveis, \% & $3,88 \mathrm{a}$ & $3,69 b$ & $3,72 b$ & $3,68 b$ & $3,84 a$ & 6,87 \\
\hline Gordura abdominal, \% & $2,82 b$ & $3,21 \mathrm{a}$ & $2,97 \mathrm{ab}$ & $2,65 b$ & $3,35 \mathrm{a}$ & 20,19 \\
\hline
\end{tabular}

Letras diferentes na mesma linha, dentro de cada variável, diferem entre si pelo teste de Tukey $(P<0.05) \quad 1$ - sem pés, cabeça e pescoço 2 - com pés, cabeça e pescoço

Fonte: Murakami et al. (1995)

Para aves leves, poedeiras (Leghorn) abatidas ao final da exploração comercial, Graner (1973) determinou o rendimento porcentual na obtenção de 36 
carcaças (sem as vísceras comestíveis, cabeça, pescoço e pés). O rendimento variou, em média, de 48,0 a $60,7 \%$.

Kondaiah et al. (1987) determinaram o peso de diversas partes de galinhas de descarte White Leghorn (leves e pesadas) e Rhode Island Red, após desossa manual a quente. $\mathrm{O}$ aumento de uma unidade de peso de aves vivas ou carcaças evisceradas de galinhas Rhode Island Red originou um rendimento em carne desossada significativamente maior que um aumento semelhante de peso em galinhas White Leghorn (leves e pesadas). Nenhuma diferença foi observada no rendimento em carne desossada entre galinhas White Leghorn (leves e pesadas). O conteúdo de gordura de galinhas White Leghorn pesadas não foi maior que em galinhas White Leghorn leves e Rhode Island Red e a porcentagem de carne limpa foi maior em galinhas Rhode Island Red, devido ao rendimento em carne da coxa e perna.

\section{2. Emulsões elaboradas com carne de aves}

Fundamentalmente, a qualidade dos produtos emulsionados está fortemente associada a uma combinação de gordura, proteína e umidade para a obtenção de uma emulsão estável. A massa crua de salsicha, por exemplo, não é uma emulsão clássica, mas sua estrutura e propriedades físicas assemelham-se às de uma emulsão verdadeira. As proteínas solubilizadas em salmoura envolvem os glóbulos de gordura como em uma emulsão do tipo óleo em água, com a gordura formando a fase dispersa, a água a fase 
contínua e as proteínas solubilizadas atuando como agentes emulsificantes (Canhos \& Dias, 1983).

A qualidade da proteína também é importante para a estabilidade da emulsão. As proteínas miofibrilares, solúveis em salmoura, são melhores agentes emulsificantes que as sarcoplasmáticas. Das proteínas miofibrilares, cerca de $65 \%$ são representadas por actina e miosina e o restante são proteínas reguladoras. A actina constitui aproximadamente $20 \%$ das proteínas miofibriliares e apresenta molécula rica em prolina, com ponto isoelétrico ao redor de 4,7 . A miosina constitui cerca de $45 \%$ das proteínas miofibrilares e tem ponto isoelétrico ao redor de 5,4 (Judge et al., 1989).

Carne com alto teor de colágeno possui uma baixa capacidade de emulsionar gordura (Jones \& Mandigo, 1982). No aspecto prático, o colágeno é indesejável, pois não é solúvel e quando submetido a $60-65^{\circ} \mathrm{C}$, em presença de umidade, sofre uma contração pronunciada. Se a temperatura for maior que $65^{\circ} \mathrm{C}$, o colágeno gelatiniza.

Swift et al. (1961), Hansen (1960) e Helmer \& Saffle (1963) relataram que proteínas solúveis em sal foram mais eficazes como emulsificadoras que proteínas solúveis em água. Os estudos indicaram que a adição de $\mathrm{NaCl}$ e extratos de proteínas à carne aumentou a capacidade de emulsificação.

Maurer \& Baker (1966) também demonstraram que em diversos cortes de várias classes de aves, peito e coxa foram superiores à pele para produzir emulsões.

Hudspeth \& May (1967) analisaram as carnes brancas e escuras de aves, inclusive frango e galinha leve, tendo encontrado uma maior proporção de proteína solúvel em solução salina $(\mathrm{NaCl}$ a $3 \%)$ na carne branca; entretanto a proteína extraída desta 
matéria-prima apresentou uma menor capacidade de emulsionar gordura que a extraída da carne escura (Tabela 6).

Tabela 6 - Teor de proteína solúvel em solução salina e capacidade de emulsionar gordura desta proteína em carnes de frango ("broiler") e de galinha leve.

\section{Proteína}

$\begin{array}{cccc}\text { Ave e } & \text { Total } & \text { Solúvel } & \text { Capac. de emulsionar } \\ \text { carne } & (\% \text { carne }) & (\% \text { proteina total }) & \text { gordura }(\mathrm{ml})^{\mathrm{a}}\end{array}$

Frango

Carne branca

22,4

37,3

18,2

Carne escura

18,7

34,1

22,2

Galinha leve

Carne branca

24,2

40,7

14,7

Carne escura

19,5

27,0

22,1

a Volume de óleo vegetal emulsionado por $100 \mathrm{mg}$ de proteína solúvel.

Fonte: Hudspeth \& May (1967)

Maurer et al. (1969) obtiveram resultados que concordaram parcialmente com os obtidos por Hudspeth \& May (1967); a coxa de galinha apresentou, porém, uma maior proporção de proteína solúvel em solução salina e esta, uma menor capacidade de emulsionar gordura, em relação ao peito.

Em ambos os trabalhos foi sugerida a existência de uma relação inversa entre a quantidade de proteína extraída por uma solução salina (concentração de proteína no extrato) e a eficiência desta na formação de uma emulsão. Quando, porém, a capacidade de emulsionar gordura foi expressa em mililitros de óleo emulsionados por um 
determinado volume de extrato, uma parte da carcaça com pequena proporção de proteína solúvel, como a pele, apresentou baixo valor para aquela propriedade (Maurer et al., 1969).

Baker et al. (1970) estudaram o efeito do $\mathrm{pH}$ sobre a qualidade de salsichas de frango; estas foram elaboradas com carne de frango ajustadas a níveis de $\mathrm{pH}$ de 4,6 a 8,6. Os resultados indicaram que em $\mathrm{pH}$ normal $(6,1)$, as salsichas de frango foram mais firmes. Abaixo de $\mathrm{pH}$ 6,1 elas rapidamente tornaram-se mais macias, devido a instabilidade da emulsão. Acima de $\mathrm{pH}$ 6,1, elas gradativamente tornaram-se mais macias, devido a menor perda de umidade. A suculência foi pouco afetada pelo $\mathrm{pH}$.

Pribis et al. (1993) conduziram estudos para avaliar os efeitos da adição de $20-40 \%$ de emulsão de pele sobre as propriedades de salsichas feitas de carne de várias classes de aves. Para amostras feitas com carne branca de aves, a plasticidade aumentou, mas a capacidade de retenção de água e a elasticidade diminuiram com o aumento da quantidade de emulsão de pele. Os resultados foram semelhantes para as amostras feitas com carne escura de aves, exceto que a capacidade de retenção de água não foi afetada. Em amostras feitas com $40 \%$ de emulsão de pele, o aumento na quantidade de água adicionada, de 20 a $30 \%$, influenciou prejudicialmente a qualidade da salsicha.

\section{3. Emulsões elaboradas com óleos vegetais}

Baker et al. (1969) na elaboração de salsichas tipo Frankfurt com carne de 
frango, verificaram que as gorduras de frango, bovina, toicinho e óleo de caroço de algodão não afetaram a suculência das salsichas. A gordura bovina e o óleo de algodão tornaram o produto mais firme que a gordura de frango somente, quando as amostras foram analisadas frias. $\mathrm{O}$ aumento do nível de gordura adicionada não afetou o sabor e o aroma; entretanto, à medida que o teor de proteína do produto foi elevado, observou-se que as salsichas tornaram-se mais consistentes.

Baker \& Darfler (1975) estudaram como a mudança de formulação afetou a aceitabilidade de salsichas feitas de carcaças de peru desossadas mecanicamente. Numa série de 5 experimentos foram determinados o efeito do tipo e nível de gordura e proteína destas salsichas. Nas séries 1, 2 e 3 usaram gordura de frango, gordura de suíno e óleo de caroço de algodão em 5 níveis $(8,13,18,23$ e 28\%); na série 4, três gorduras e 2 níveis de óleo (13 e 23\%); na série 5, 4 níveis de proteínas $(9,12,15$ e 18\%). Os metódos de avaliação incluiram viscosidade e estabilidade da emulsão crua, estabilidade da emulsão cozida, valores de ruptura e rendimento. Em geral, níveis mais altos de gordura produziram salsichas mais firmes, com emulsão mais viscosa e um rendimento maior. O tipo de gordura a níveis equivalentes tinha pouco ou nenhum efeito sobre valores de ruptura ou rendimentos, mas as emulsões de gordura de suíno foram ligeiramente mais viscosas. A análise sensorial mostrou pouca diferença entre salsichas feitas com gordura de frango e gordura de suíno a níveis equivalentes, mas aquelas feitas com óleo de caroço de algodão foram menos suculentas e menos saborosas e portanto menos aceitáveis. $\mathrm{O}$ aumento do nível de proteína nas salsichas elevou a força de ruptura, viscosidade da emulsão e rendimento e diminuiu a maciez e a suculência. 
Marquez et al. (1989) substituiram gordura bovina por óleo vegetal (canola) na elaboração de salsichas. A proporção de carnes foi de $4: 6$ (partes de carne bovina: carne suína magra). A composição química destas salsichas correspondeu à do produto comercial. As características de qualidade organoléptica, na substituição de 40 a $50 \%$, não foram significativamente diferentes em termos de cor, sabor e textura, do produto controle. Do ponto de vista tecnológico, segundo os autores, a substituição parcial de gordura animal por óleo vegetal em produtos cárneos é praticável. Esta substituição tem um impacto positivo no valor nutricional do produto final. A presença de $25 \%$ a $56 \%$ de óleo no total do conteúdo de gordura resultou no acréscimo do nível de ácidos graxos poli-insaturados e uma redução de $50 \%$ na proporção de saturados/ poli-insaturados.

Park et al. (1989) desenvolveram estudo para avaliar as características de salsichas de baixo conteúdo de calorias quando elaboradas com ácidos graxos monoinsaturados (na forma de óleo de girassol) e ômega 3 (na forma de óleo de peixe), e examinar a limitação do uso destes em formulações comerciais. Observou-se que a substituição de gordura animal por estes óleos apresentou pouco efeito na estabilidade da emulsão. Salsichas elaboradas com $5 \%$ de óleo de peixe apresentaram indesejável odor de peixe quando observadas através de análise sensorial. A incorporação de máxima quantidade de óleo de girassol, em salsichas de carnes bovina e suína de baixo teor de gordura e em salsichas apenas de carne bovina aumentaram o ácido oleico em $34 \%$ e $62 \%$ respectivamente, e a proporção monoinsaturados/saturados em $178 \%$ e $468 \%$ respectivamente, em relação a um produto regular (30\% de gordura), contendo somente gordura animal. Uma análise, sensorial e instrumental do perfil da textura mostrou que a redução de gordura total 
causou problemas na textura, especialmente aumentando a firmeza e a elasticidade, e uma diminuição da suculência.

Park et al. (1990) compararam as propriedades sensoriais e reológicas de salsichas elaboradas com óleo de girassol e as de salsichas contendo apenas gordura animal, ambas contendo quantidades variadas de gordura total. Observaram que mudanças na formulação tem pouco efeito no rendimento do processamento. Salsichas elaboradas com óleo de girassol tiveram um maior aumento, de 180 a $241 \%$, na proporção de ácidos monoinsaturados/saturados, quando comparadas ao produto controle com similar nível total de gordura. Os dados da análise sensorial e da análise instrumental para a textura indicaram que salsicha com baixo teor de gordura (14 a 16\%) e alta quantidade de água foram tão aceitáveis quanto as salsichas controle com $28 \%$ de gordura (gordura animal), e não tiveram problemas de textura.

Xiong et al. (1992) estudaram o efeito de lipídios sobre as propriedades de géis de proteína de frango preparados com diferentes tipos de fibras musculares (peito, coxa e perna). Miofibrilas foram misturadas com quatro tipos de emulsões (óleo de canola, óleo de girassol, toicinho e gordura do leite), cada uma a $0 ; 2 ; 5 ; 7,5$ ou $10 \%$ de óleo ou gordura. Géis foram induzidos pelo aquecimento das misturas de 10 a $70^{\circ} \mathrm{C}$. A resistência do gel com miofibrila de peito aumentou significativamente com adição de $5 \%$ de gordura de leite ou $10 \%$ de toicinho, mas foi pouco afetada pelos óleos vegetais. A adição de 5\% de gordura e óleos melhorou a capacidade de retenção de água dos géis, mas não alterou a composição das proteínas não coaguladas na matriz. Os resultados 
sugerem que o reforço das redes dos géis pelos glóbulos de gordura foi influenciado pelo estado físico da emulsão e tipo de fibra muscular.

No Departamento de Ciência e Tecnologia Agroindustrial da Escola Superior de Agricultura "Luiz de Queiroz", foram realizados trabalhos com o objetivo de estudar a utilização de óleos vegetais na obtenção de emulsões com a carne de frango (Bortoluzzi, 1993; Moreira, 1994).

Bortoluzzi (1993) estudou a substituição de gordura animal (toicinho) por óleos vegetais (soja, girassol, milho e algodão), em fiambres (emulsões) curados e defumados elaborados com carne de frango. Primeiro elaborou fiambre a partir de três níveis de toicinho $5 ; 15$ e $25 \%$, com a finalidade de selecionar um produto controle para as análises sensoriais das demais etapas. Na segunda etapa utilizou óleo de soja nos níveis de $10 ; 15$ e $20 \%$ e, na terceira etapa, 7,$5 ; 12,5$ e $17,5 \%$, para a elaboração do produto. Nesta fase, selecionou-se o nível de óleo $(12,5 \%)$ a ser utilizado na quarta etapa, em que foram utilizados diferentes óleos vegetais. Chegou às seguintes conclusões: óleos vegetais podem substituir a gordura suína na elaboração de fiambres de frango, obtendo-se um produto de alto valor nutricional e boa aceitação; níveis superiores a $15 \%$ de óleo de soja resultaram em instabilidade da emulsão; os fiambres com óleos vegetais apresentaram ácidos graxos com maior insaturação (soja e girassol, 78\%; milho e algodão, 68\%) que fiambres com gordura animal $(53,38 \%)$.

Moreira (1994) observou os efeitos da incorporação de proteína texturizada de soja (PTS) em algumas características químicas e organolépticas de fiambre de carne de frango elaborados com óleo vegetal. Na primeira etapa elaborou fiambres com 
12,5\% de óleo de soja (em relação à mistura carne, PTS e óleo) e utilizou PTS nos níveis de $0 ; 5 ; 10 ; 15$ e $20 \%$, em substituição à carne mista. Os produtos não diferiram significativamente para sabor, maciez e suculência; com a utilização de PTS não se alterou o rendimento no processamento térmico, houve uma melhora da cor e da aparência geral do produto, devendo-se este fato ao corante presente na PTS. Na segunda etapa utilizou óleo de soja sem PTS e com PTS e também óleo de canola com e sem PTS. Os resultados foram semelhantes aos da primeira etapa. Concluiu-se que a proteína da carne de frango pode ser substituída parcialmente por PTS, sem prejudicar a qualidade da emulsão quando se elabora fiambre de carne de frango com óleos vegetais (soja e canola).

\section{4. Fiambres elaborados com carne de frango}

De acordo com Sanz Egaña (1967), fiambre é um produto que, depois de assado ou cozido, é resfriado para ser consumido frio. Entre os embutidos cozidos há exemplos de fiambres, assim como há fiambres que não são embutidos, mas processados térmicamente em formas metálicas; a grande variedade de fiambres existentes compreende também produtos elaborados com emulsões de carne e outros preparados com carne não emulsionada, sendo ainda possível uma combinação dos dois tipos (Graner, 1987b).

As Normas Técnicas Especiais, relativas a alimentos e bebidas, do Estado de São Paulo (São Paulo, 1978), citadas por Graner (1985), definem afiambrados como "produtos elaborados com carnes bovina e/ ou suína, trituradas convenientemente, 
podendo ser adicionados gorduras, condimentos, queijo em cubos, sendo processados por cozimento em água ou assados em forno". Segundo as mesmas Normas, são sinônimos "fiambre", "afiambrado" e "pão-de-carne", podendo estas denominações ser seguidas de palavras indicativas da espécie da qual a carne é proveniente (fiambre de bovino, fiambre de frango).

Graner (1974) obteve fiambre com a carne mista de galinhas leves descartadas da postura, estudando o efeito de algumas variáveis de processamento sobre propriedades organolépticas, fisicas e químicas do produto.

Schneider et al. (1981) elaboraram embutidos defumados e cozidos em estufa, com carne mista de frango e parte desta matéria-prima substituída por carne bovina e suína, utilizando também farinha texturizada de soja.

Graner (1987b) elaborou fiambre de frango a partir de carne mista, separada manualmente do peito, coxas e pernas, através de emulsificação, cura e defumação. Foram utilizadas duas formulações (com e sem pele), resultando um produto de boa qualidade organoléptica, sem diferenças significativas.

Yang \& Chen (1988) estudaram o efeito da concentração de nitrito de sódio e do tempo de cura sobre o desenvolvimento da cor em fiambres de frango. Pedaços de carne de frango (peito e carne escura) foram curados com uma combinação de 5 concentrações de $\mathrm{NaNO}_{2}(0,50,100,156$ e 200ppm) e três tempos de cura $(1,2$ e 3 horas). Partes de carne curada foram colocadas dentro de uma embalagem para formar pedaços de $6 \mathrm{~cm}$ de diametro ( $300 \mathrm{~g}$ cada uma) antes de serem cozidos até a temperatura interna de $68,3^{\circ} \mathrm{C}$. Fatias dos produtos preparados foram embaladas e armazenadas (de 2 
a $4^{\circ} \mathrm{C}$ e $-18^{\circ} \mathrm{C}$ ). A cor interna foi medida semanalmente durante 3 semanas de armazenamento $\left(2\right.$ a $\left.4^{\circ} \mathrm{C}\right)$, enquanto que para as amostras congeladas a cor foi avaliada após 1 mes. Concluiu-se que o efeito de desenvolvimento de cor de $\mathrm{NaNO}_{2}$ não aumentou além de 50ppm e 1 hora de tempo de cura.

Graner (1992) obteve fiambres com as carnes brancas (do peito) e escura (das coxas e pernas) de frango, separadamente. Foram obtidos fiambres curados e defumados com boa qualidade sensorial, adequado nível de proteína e baixo conteúdo calórico, do tipo semi-conserva. O rendimento foi maior na elaboração do fiambre de carne branca, o qual foi preferido na avaliação sensorial, em relação ao produto de carne escura.

Bortoluzzi (1993) estudou o aproveitamento de partes comestíveis de frango, juntamente com óleo vegetal, verificando que os óleos vegetais podem substituir a gordura suína na elaboração de fiambres de frango do tipo emulsão, obtendo-se um produto de alto valor nutricional e boa aceitação.

Moreira (1994) estudou os efeitos da incorporação de proteína texturizada de soja em algumas características químicas e organolépticas de fiambres de carne de frango elaborados com óleo vegetal (tipo emulsão). Constatou-se que a utilização de PTS não afetou de maneira significativa os atributos sensoriais de sabor, maciez e suculência e a proteina da carne de frango pode ser parcialmente substituída pela proteína texturizada de soja, sem prejudicar a qualidade da emulsão quando se elabora fiambre de carne de frango com óleos vegetais.

Roça et al. (1994) verificaram a influência da proteína texturizada de soja (PTS a 5; 10 e 15\%) nas características sensoriais, químicas, físico-químicas, no proces- 
samento do fiambre de frango. Os resultados estatísticos dos atributos sensoriais dos produtos avaliados não foram significativos. Constatou-se que a capacidade de absorção e retenção de água aumentou significativamente, porém tal fato não ocorreu com relação ao rendimento em peso do produto final. Observou-se, ainda, uma significativa diminuição da umidade e do extrato etéreo dos fiambres processados. 


\section{MATERIAL E MÉTODOS}

A parte experimental deste projeto foi desenvolvida em laboratórios do Departamento de Ciência e Tecnologia Agroindustrial da Escola Superior de Agricultura "Luiz de Queiroz" da Universidade de São Paulo (USP), em Piracicaba - São Paulo.

\subsection{Material}

\subsubsection{Matéria-prima}

A matéria-prima cárnea foi constituída de 30 carcaças de poedeiras leves raça Leghorn e linhagem Isababcock oriundas da Granja Saito S.A. - SP, as quais apresentaram um período de postura de 19 a 72 semanas; após este período foram descartadas e enviadas ao Matadouro Avícola Flamboiã Ltda - Cabreúva - SP, onde foram adquiridas sem cabeça, pescoço e vísceras comestíveis, congeladas, com peso médio de 1195,81g. Também foram adquiridas 12 carcaças de frangos de corte linhagem Hubbard Peterson (sem cabeça, pescoço e vísceras comestíveis) resfriadas, com peso médio de 
1961,41g, em estabelecimento comercial de Piracicaba - SP (Varejão Frangolândia) e procedentes do Fricock Frigorificação Avicultura Ind. e Com. Ltda - Rio Claro - SP, com a finalidade de comparação (controle).

As carcaças de poedeiras leves foram transportadas em caixa térmica Pizzinatto, envoltas em barras de gelo e mantidas sob congelamento a $-25^{\circ} \mathrm{C}$ até o início das operações de corte e desossa. As mesmas foram então descongeladas por um período de $48 \mathrm{~h}$, sob refrigeração a $0^{\circ} \mathrm{C}$, pesadas e subdivididas, obtendo-se os seguintes cortes de cada uma: peito, coxas e pernas, coxinhas das asas, dorso e asas. Os cortes peito, coxas e pernas e coxinhas das asas foram desossados manualmente, retirando-se a pele e o excesso de gordura.

As carnes brancas (peito) e escuras (pernas e coxas e coxinhas das asas) foram cortadas em pedaços, misturadas e moídas duas vezes, em moedor de carne elétrico com disco de orificios de $9 \mathrm{~mm}$, misturadas novamente e embaladas em sacos de polietileno (em quantidades suficientes para a elaboração do produto), fechadas com arame plastificado, após remoção de ar, e armazenadas em congelador a $-25^{\circ} \mathrm{C}$ (Figura 1). 
Figura 1. Fluxograma da obtenção da matéria-prima cárnea

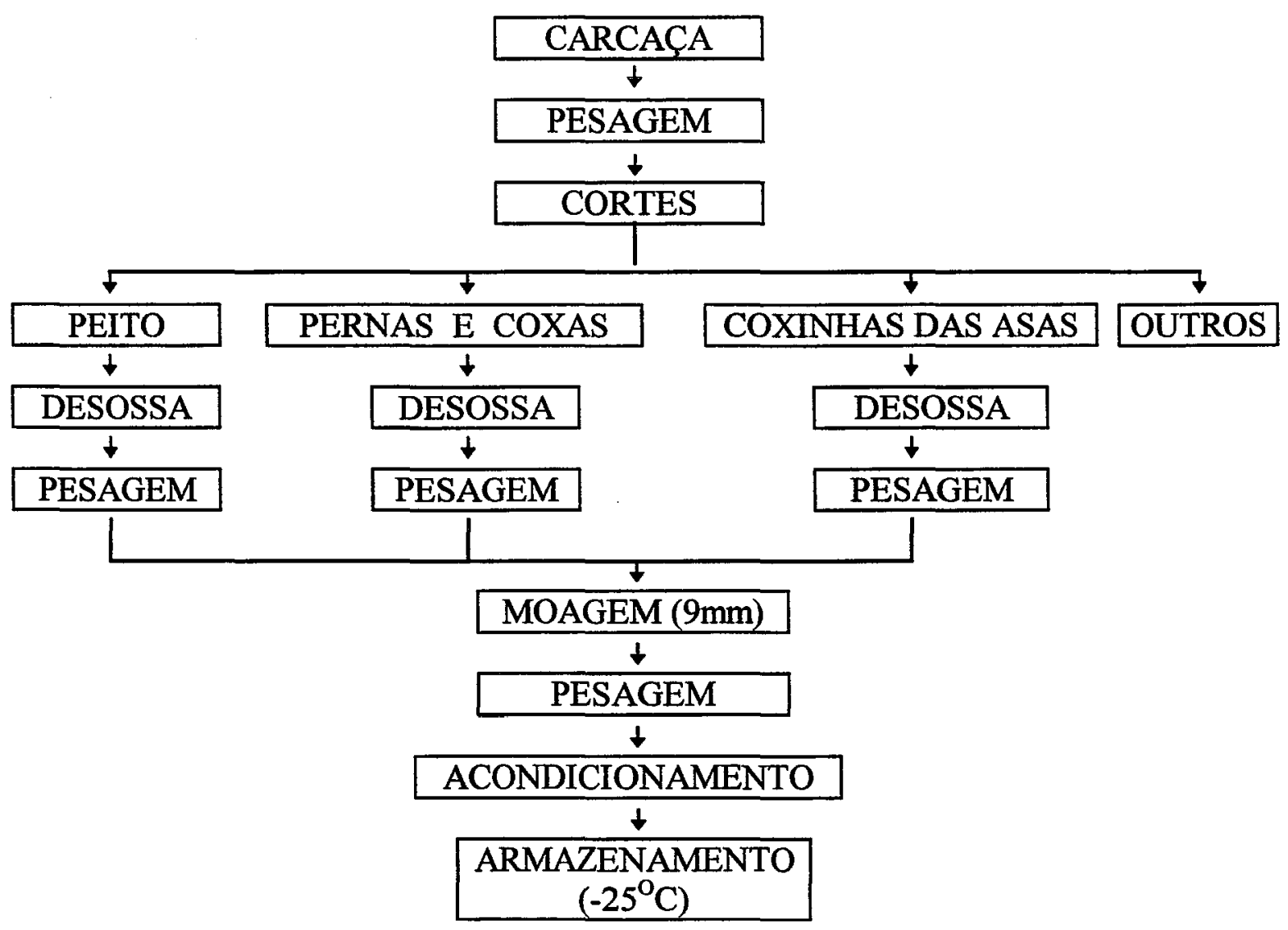

Os óleos vegetais (soja, milho, girassol e canola) utilizados para a elaboração do produto foram selecionados a partir da disponibilidade no mercado. Marcas: Liza (soja), Mazola (milho), Cocinero (girassol) e Ville (canola).

Outros ingredientes não cárneos e aditivos também foram utilizados: gelo triturado e água, sal refinado, açúcar refinado, pimenta branca, páprica doce, glutamato monossódico, nitrito de sódio e ácido ascórbico. 


\subsection{Métodos}

\subsubsection{Elaboração dos fiambres}

O produto foi elaborado em duas etapas, de acordo com o fluxograma apresentado na Figura 2, utilizando-se ingredientes não cárneos e aditivos conforme a Tabela 7.

$\mathrm{Na}$ Etapa I foram elaborados fiambres utilizando-se carne de poedeira leve (1313g - 87,5\%) e um único nível $(187 \mathrm{~g}-12,5 \%)$ de diferentes óleos vegetais (soja, milho, girassol e canola).

A carne mista, parcialmente descongelada, foi transferida para um triturador ("cutter"), adicionando-se 1/3 do gelo, sal e demais ingredientes e aditivos até a obtenção da emulsão; a temperatura final da massa no "cutter" foi de $12^{\circ} \mathrm{C}$.

A emulsão crua foi transferida para 3 formas descartáveis de alumínio, que foram pesadas e levadas a defumador de alvenaria. A defumação/pasteurização foi realizada a $50-60^{\circ} \mathrm{C}$ por $30 \mathrm{~min}$. sem fumaça com chaminé aberta, a $60-70^{\circ} \mathrm{C}$ por $1 \mathrm{~h}$ com fumaça e chaminé semi-aberta e a $70-90^{\circ} \mathrm{C}$ com fumaça e chaminé semi-aberta até que a temperatura interna da emulsão atingisse $71^{\circ} \mathrm{C} . \mathrm{O}$ resfriamento foi realizado em bandejas com gelo e água, até que o produto atingisse $40^{\circ} \mathrm{C}$ (temperatura interna), quando as formas foram transferidas para refrigerador a $0^{\circ} \mathrm{C}$. Após 24 horas, a emulsão cozida e resfriada foi novamente pesada para determinação do rendimento no processamento. 
Figura 2. Fluxograma do processamento na elaboração de fiambres de poedeiras e frangos.
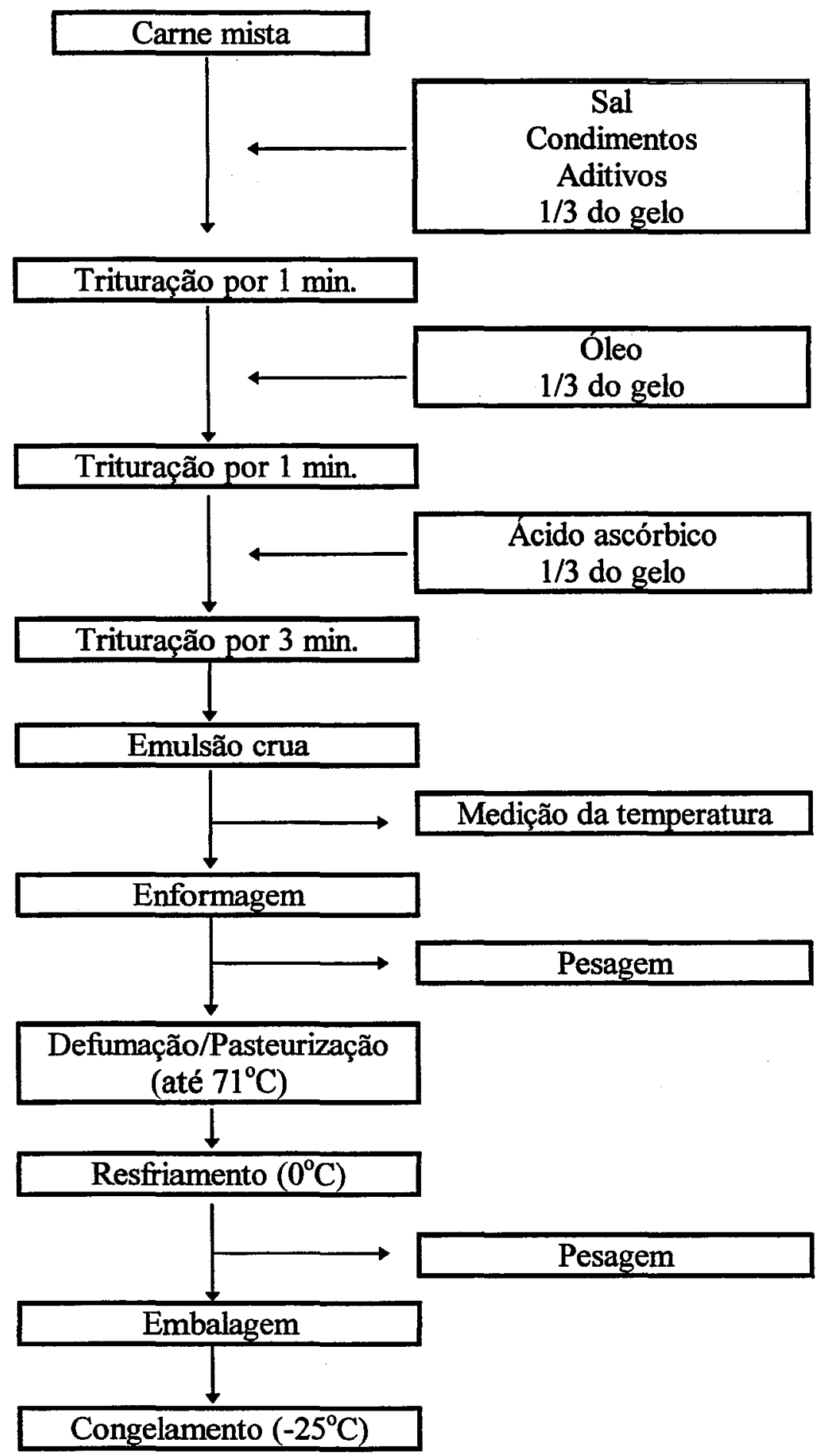
Tabela 7 - Ingredientes não cárneos e aditivos utilizados na elaboração dos fiambres (em relação aos ingredientes cárneos e óleo)

\begin{tabular}{|c|c|c|}
\hline Ingredientes e Aditivos & $\%$ & $\mathrm{~g}$ \\
\hline Gelo triturado e água & 10 & 150,00 \\
\hline Sal refinado ${ }^{\mathrm{a}}$ & 2,5 & 37,50 \\
\hline Nitrito de sódio ${ }^{\mathrm{b}}$ & 0,015 & 0,225 \\
\hline Açúcar refinado & 0,15 & 2,25 \\
\hline Pimenta branca & 0,15 & 2,25 \\
\hline Páprica doce & 0,15 & 2,25 \\
\hline Glutamato monossódico & 0,15 & 2,25 \\
\hline Ácido ascórbico ${ }^{\mathrm{b}}$ & 0,05 & 0,75 \\
\hline
\end{tabular}

As peças foram desenformadas, embaladas em folhas de alumínio e sacos de polietileno fechados com arame plastificado, após remoção de ar, e congeladas a $-25^{\circ} \mathrm{C}$, até a realização da análise sensorial, que foi realizada dentro de um período de dois meses. Meia peça de cada formulação foi separada para análise química, antes do congelamento.

Na Etapa II utilizaram-se carne de poedeira e carne de frango com óleo de soja e óleo de milho, conforme descrito na Etapa I. 


\subsection{Análises}

\subsubsection{Análise química da matéria-prima}

Da matéria-prima, antes de ser congelada, foram retiradas porções representativas, que foram moídas por mais duas vezes em moedor de carne elétrico (disco com orificio de $5 \mathrm{~mm}$ de diâmetro), misturadas e acondicionadas em frascos de vidro com tampas plásticas, permitindo fechamento hermético. Estas amostras, após a determinação do $\mathrm{pH}$, foram transferidas para um congelador e mantidas a $-25^{\circ} \mathrm{C}$ até a realização das demais análises, quando foram descongeladas em refrigerador a $0^{\circ} \mathrm{C}$ por 36 horas.

\section{Umidade}

$\mathrm{O}$ teor de umidade foi determinado por secagem em estufa com circulação mecânica de ar a $125^{\circ} \mathrm{C}$ durante 4 horas (Association of Official Analytical Chemists A.O.A.C., 1970). Foram feitas 3 repetições por amostra.

\section{Proteína}

O teor de proteína foi determinado por uma combinação de métodos: macro-Kjeldahl (Jacobs, 1958), para a digestão da amostra; o material digerido foi diluído e uma alíquota utilizada para a determinação do nitrogênio (N) pelo método 
micro-Kjeldahl (Association of Official Analytical Chemists - A.O.A.C., 1970). Foram feitas 2 repetições por amostra.

Uma vez determinados os teores de umidade $(U)$ e de proteína $(P)$, a relação U/P foi calculada.

\section{Lipídios}

O teor de lipídios foi determinado pelo método de Babcock modificado segundo Kelley et al. (1954). Foram feitas 2 repetições por amostra.

\section{pH}

$\mathrm{O} \mathrm{pH}$ foi determinado com um potenciômetro digital em uma mistura, em partes iguais, de amostra e de água recém-destilada.

\subsubsection{Análise química do produto}

Cada meia peça correspondente a uma formulação foi cortada em pedaços e moída por 3 vezes em moedor de carne elétrico com disco de orificio de $5 \mathrm{~mm}$ e acondicionada em frascos de vidro com fechamento hermético; após a determinação do $\mathrm{pH}$, foram armazenadas em congelador em temperatura de $-25^{\circ} \mathrm{C}$, até a realização das demais análises.

Os teores de umidade, proteína, lipídios e o $\mathrm{pH}$ foram determinados como descrito para a matéria-prima. 


\section{Cinza}

O teor de cinza foi determinado segundo Association of Official Analytical Chemists - A.O.A.C., 1970, através de mineralização da amostra a $525^{\circ} \mathrm{C}$ em mufla. Foram feitas 3 repetições por amostra.

\subsubsection{Análise sensorial}

Para verificar a aceitabilidade dos produtos elaborados na Etapa I foi realizado um teste de consumidor, com 80 provadores não treinados. As amostras foram servidas à temperatura ambiente em quantidades em torno de $10 \mathrm{~g}$, sob luz natural e codificadas com 3 letras e a apresentação foi aleatória. Utilizou-se uma escala hedônica estruturada de 9 pontos e foi solicitado aos provadores que adicionassem comentários (APÊNDICE 1) (Mori, 1982).

Através deste teste escolheram-se dois tratamentos para comparar com os fiambres de frango na Etapa II.

Para analisar a qualidade sensorial dos produtos, as amostras foram apresentadas a 57 provadores não treinados, como na etapa anterior. Avaliaram-se os seguintes atributos de qualidade: sabor, maciez, suculência e cor, sendo que os provadores receberam antecipadamente uma lista de definições dos atributos considerados. Para a qualidade global, utilizou-se uma escala hedônica estruturada de 9 pontos (APÊNDICE 2) (Arima et al., 1994). 


\subsubsection{Análise estatística}

Para avaliação dos dados obtidos da análise sensorial aplicou-se a técnica de análise de variância a $5 \%$ de probabilidade, com utilização do teste $\mathrm{F}$ referente ao delineamento inteiramente casualizado adotado. Quando necessário, as médias foram comparadas utilizando-se o teste t-Student, ao mesmo nível de significância (Pimentel Gomes, 1987). 


\section{RESULTADOS E DISCUSSÃO}

\subsection{Rendimento na desossa manual}

A Tabela 8 apresenta os valores obtidos para os pesos médios e rendimento porcentual médio na desossa manual de cortes (peito, pernas e coxas, coxinhas das asas) para as carcaças de poedeiras leves.

Tabela 8 - Pesos médios e rendimento porcentual médio na desossa manual de cortes (peito, pernas e coxas e coxinhas das asas) de poedeiras leves (30 carcaças).

\begin{tabular}{lcccc}
\hline & $\begin{array}{c}\text { PESO MÉDIO } \\
\text { CARCAÇAS }\end{array}$ & PEITO & $\begin{array}{c}\text { PERNAS E } \\
\text { COXAS }\end{array}$ & $\begin{array}{c}\text { COXINHAS } \\
\text { DAS ASAS }\end{array}$ \\
\hline Pesos $(\mathrm{g})^{\mathrm{a}}$ & 1195,81 & 176,19 & 178,38 & 29,44 \\
\hline Rendimento $(\%)^{\mathrm{b}}$ & 1195,81 & 14,73 & 14,91 & 2,46 \\
\hline $\begin{array}{l}{ }^{\mathrm{a}} \text { Carne desossada sem pele e sem gordura } \\
\text { b } \text { Em relação ao peso da carcaça }\end{array}$ \\
\hline
\end{tabular}

Notamos que o rendimento do peito $(14,73 \%)$ foi semelhante ao rendimento das pernas e coxas $(14,91 \%)$; as coxinhas das asas apresentaram um rendimento de 2,46\%. Graner (1987a) e Bortoluzzi (1993) também observaram valores semelhantes 
para peito (18\%) e pernas e coxas (18\%); sendo que Moreira (1994) encontrou rendimento do peito $(17,60 \%)$ ligeiramente inferior ao rendimento de pernas e coxas (19,56\%). Kondaiah et al. (1987) não observaram diferença no rendimento em carne desossada entre galinhas White Leghorn leves e pesadas.

A Tabela 9 apresenta os valores médios dos pesos e dos rendimentos porcentuais da carne branca (peito) e escura (coxas e pernas e coxinhas das asas), após a sua limpeza e corte, na desossa manual das 30 carcaças de poedeiras leves utilizadas no experimento. Na mesma tabela encontra-se, também, a proporção entre as carnes branca e escura. Pode-se notar que o rendimento na obtenção da carne escura $(17,37 \%)$ foi ligeiramente superior ao rendimento da carne branca (14,73\%). Bortoluzzi (1993) encontrou rendimentos semelhantes na obtenção de carne branca $(18,29 \%)$ e de carne escura (18,38\%). Para Moreira (1994) o rendimento na obtenção da carne escura $(22,13 \%)$ foi maior que o rendimento da carne branca $(17,63 \%)$.

A partir das carnes branca e escura, obteve-se um rendimento de $32,11 \%$ de carne mista. Observou-se uma proporção entre as carnes branca e escura de 45,90 e $54,10 \%$, respectivamente, contra os valores de 49,89 e $50,12 \%$ observado por Bortoluzzi (1993) e os valores de 44,33 e 55,67\% encontrados por Moreira (1994), para frangos. 
Tabela 9 - Peso e rendimento porcentual na obtenção de carne branca (peito) e escura (pernas e coxas e coxinhas das asas) de poedeiras leves, após limpeza e corte.

\begin{tabular}{cccc}
\hline & \multicolumn{3}{c}{ CARNES } \\
\cline { 2 - 4 } VARIÁVEIS & BRANCA & ESCURA & MISTA \\
\hline No de Carcaças & 30 & 30 & 30 \\
Peso (g) das carcaças & 35874,50 & 35874,50 & 35874,50 \\
Peso (g) das carnes após limpeza & 5285,70 & 6234,94 & 11520,64 \\
Rendimento (\%) em relação às carcaças & 14,73 & 17,37 & 32,11 \\
Proporção entre carne branca e escura & 45,90 & 54,10 & 100,00 \\
\hline
\end{tabular}

\section{2. Composição química da matéria-prima}

A composição química da carne mista moída de poedeira e frango, utilizada na elaboração do fiambre, encontra-se na Tabela 10.

Tabela 10 - Composição química da carne

\begin{tabular}{cccccc}
\hline Matéria-prima & $\begin{array}{c}\text { Umidade } \\
\%\end{array}$ & $\begin{array}{c}\text { Proteína } \\
\%\end{array}$ & $\begin{array}{c}\text { Lipídios } \\
\%\end{array}$ & $\mathrm{U} / \mathrm{P}$ & $\mathrm{pH}$ \\
\hline $\begin{array}{c}\text { carne mista } \\
\text { moída de poedeira } \\
\text { carne mista }\end{array}$ & 74,23 & 19,60 & 3,75 & 3,78 & 6,03 \\
\begin{tabular}{c} 
moída de frango \\
\hline
\end{tabular} & 74,35 & 18,15 & 4,50 & 4,09 & 5,98 \\
\hline
\end{tabular}


A composição química da carne de poedeira apresentou um teor de umidade semelhante a carne de frango, porém o teor de proteína foi superior e o teor de lipídios inferior quando comparado à carne de frango.

A relação umidade/proteína (U/P) $(3,78)$ foi ligeiramente inferior à da carne de frango, estando esta de acordo com os trabalhos realizados por Bortoluzzi(1993) e Moreira(1994).

$\mathrm{O} \mathrm{pH}(6,03)$ foi semelhante ao da carne de frango, que por sua vez foi semelhante aos valores observados por Bortoluzzi (1993) e Moreira (1994) e inferior ao encontrado por Roça (1986).

\subsection{Rendimentos na elaboração do produto}

Os rendimentos no tratamento térmico, seguido de resfriamento na elaboração dos produtos, encontram-se nas Tabelas 11 e 12 , respectivamente, para as Etapas I e II. 
Tabela 11 - Rendimentos no tratamento térmico, seguido de resfriamento, de fiambre de carne de poedeira elaborado com diferentes óleos (Etapa I).

\begin{tabular}{ccc}
\hline & MÉDIAS \\
\cline { 2 - 2 } ÓLEOS & RENa & 94,13 \\
Milho & 94,93 \\
Girassol & 95,71 \\
Canola & 95,10 \\
\hline
\end{tabular}

Tabela 12 - Rendimentos no tratamento térmico, seguido de resfriamento, de fiambre de carne de poedeira e frango elaborado com óleo de soja e milho (Etapa II).

\begin{tabular}{lc}
\hline & MEDIAS \\
\cline { 2 - 2 } TRATAMENTOS & RENDIMENTO (\%) \\
\hline $\begin{array}{c}\text { Carne de poedeira } \\
\text { e óleo de soja }\end{array}$ & 95,08 \\
Carne de poedeira & \\
e óleo de milho & 94,64 \\
Carne de frango & \\
e óleo de soja & 95,58 \\
Carne de frango & \\
e óleo de milho & 94,63 \\
\hline
\end{tabular}


Nas Etapas I e II foram observados valores semelhantes, quanto ao rendimento; o mesmo foi constatado por Bortoluzzi (1993), Roça et al. (1994), Moreira (1994) e Park et al. (1990). Baker \& Darfler (1975) afirmaram que níveis mais altos de lipídios e proteínas diminuiram as perdas durante a cocção. Park et al. (1990) observaram que mudanças na formulação tem pouco efeito no rendimento do processamento.

Nas condições do presente trabalho, na Etapa I, pode-se estimar que $100 \mathrm{~kg}$ de poedeiras leves (na forma de carcaça congelada), correspondem a 34,$65 ; 35,13$; 34,98 e $34,43 \mathrm{~kg}$ de fiambre utilizando-se o nível de $12,5 \%$ de óleo de soja, milho, girassol e canola, respectivamente e que $100 \mathrm{~kg}$ de carne mista, correspondem a 113,29; 114,$85 ; 114,35$ e $112,55 \mathrm{~kg}$ de produto, a nível de $12,5 \%$ de óleos de soja, milho, girassol e canola, respectivamente.

A média entre os tratamentos foi de $34,79 \mathrm{~kg}$ de fiambre para $100 \mathrm{~kg}$ de carcaças de poedeiras e $113,76 \mathrm{~kg}$ de produto para $100 \mathrm{~kg}$ de carne mista.

Na Etapa II, pode-se estimar que $100 \mathrm{~kg}$ de poedeiras leves (na forma de carcaça congelada), correspondem a 33,44 e $34,35 \mathrm{~kg}$ de fiambre, elaborados com $12,5 \%$ de óleos de soja e milho, respectivamente e que $100 \mathrm{~kg}$ de carne mista correspondem a 111,73 e 114,78kg de produto, também elaborados com óleos de soja e milho, respectivamente, a nível de 12,5\%. O rendimento para $100 \mathrm{~kg}$ de frango (na forma de carcaça resfriada) foi de 38,56 e $37,42 \mathrm{~kg}$ de fiambre (óleos de soja e milho, respectivamente) e para $100 \mathrm{~kg}$ de carne mista foi de 113,90 e 110,5kg, também elaborados com óleos de soja e milho, a nível de $12,5 \%$. 
A média entre os tratamentos foi de $33,89 \mathrm{~kg}$ de fiambre para $100 \mathrm{~kg}$ de carcaças de poedeiras e $113,25 \mathrm{~kg}$ de produto para $100 \mathrm{~kg}$ de carne mista. Para o produto controle a média foi de $37,99 \mathrm{~kg}$ de fiambre para $100 \mathrm{~kg}$ de carcaças de frango e $112,20 \mathrm{~kg}$ de produto para $100 \mathrm{~kg}$ de carne mista.

\subsection{Composição química do produto}

A composição química do produto encontra-se nas Tabelas 13 e 14, correspondendo às Etapas I e II. Nas duas etapas observou-se um aumento no teor de lipidios, correspondente ao adicionado na formulação, e, consequentemente, uma diminuição nos níveis de umidade e proteína.

Tabela 13 - Composição química dos fiambres elaborados a partir de carne de poedeira e óleos vegetais (soja, milho, girassol e canola) (Etapa I)

\begin{tabular}{ccccccc}
\hline Óleos & $\begin{array}{c}\text { Umidade } \\
\%\end{array}$ & $\begin{array}{c}\text { Proteína } \\
\%\end{array}$ & $\begin{array}{c}\text { Lipídios } \\
\%\end{array}$ & $\begin{array}{c}\text { Cinza } \\
\%\end{array}$ & $\mathrm{U} / \mathrm{P}$ & $\mathrm{pH}$ \\
\hline Soja & 64,69 & 13,78 & 17,00 & 3,02 & 4,69 & 6,21 \\
Milho & 64,00 & 14,65 & 16,25 & 3,06 & 4,36 & 6,23 \\
Girassol & 64,98 & 13,34 & 16,75 & 3,01 & 4,87 & 6,21 \\
Canola & 65,38 & 13,88 & 16,50 & 2,92 & 4,71 & 6,21 \\
\hline Média & 64,76 & 13,91 & 16,62 & 3,00 & 4,65 & 6,21 \\
\hline
\end{tabular}


Tabela 14 - Composição química dos fiambres elaborados a partir de carne de poedeira e frango com óleo de soja e milho (Etapa II)

\begin{tabular}{cccccccc}
\hline $\begin{array}{c}\text { Carne } \\
\text { mista }\end{array}$ & Óleos & $\begin{array}{c}\text { Umidade } \\
\%\end{array}$ & $\begin{array}{c}\text { Proteína } \\
\%\end{array}$ & $\begin{array}{c}\text { Lipídios } \\
\%\end{array}$ & $\begin{array}{c}\text { Cinza } \\
\%\end{array}$ & U/P & pH \\
\hline & Soja & 65,05 & 14,21 & 16,25 & 3,03 & 4,57 & 6,18
\end{tabular}

Poedeira

\begin{tabular}{ccccccc} 
Milho & 65,17 & 14,43 & 16,00 & 3,00 & 4,51 & 6,16 \\
\hline Média & 65,11 & 14,32 & 16,12 & 3,01 & 4,54 & 6,17 \\
\hline Soja & 64,96 & 13,12 & 17,50 & 3,08 & 4,95 & 6,09
\end{tabular}

Frango

\begin{tabular}{ccccccc} 
Milho & 64,55 & 13,56 & 16,75 & 3,08 & 4,76 & 6,03 \\
\hline Média & 64,75 & 13,34 & 17,12 & 3,08 & 4,85 & 6,06 \\
\hline
\end{tabular}

A relação umidade/proteína (U/P), para todos os produtos elaborados, foi superior a 3,5. Este limite $(3,5)$, estabelecido pela legislação para embutidos cozidos, vem sendo questionado por vários autores, pois não atende às especificações técnicas que ocorrem na prática industrial (Bortoluzzi, 1993), e está sendo revisto.

A composição química dos fiambres elaborados com carne de poedeira apresentou um teor de lipídios semelhante aos elaborados com carne de frango. Em estudo realizado por Bortoluzzi (1993), verificou-se que, na elaboração de produtos semelhantes, utilizando-se os mesmos óleos, destacaram-se os elaborados com óleo de soja, pois os teores de ácidos graxos saturados e insaturados foi de 21,75\% e 78,24\%, respectivamente, em relação ao óleo de milho (31,93\% e 68,05\%). 
$\mathrm{O} \mathrm{pH}$ apresentou-se superior a 6,1 para todos os produtos desenvolvidos, com exceção dos elaborados com carne de frango, para os quais foi ligeiramente inferior (6,09 e 6,03); para Baker et al. (1970), a este nível de $\mathrm{pH}(6,1)$, observa-se uma maior firmeza em salsichas; uma redução nestes valores causa a instabilidade da emulsão e um aumento na maciez.

Não houve diferenças quanto ao teor de cinza. $\mathrm{O}$ aumento do teor de cinza da matéria-prima (em torno de 1,0) para o produto final (média de 3,02), deve-se principalmente à adição de sal comum, na proporção de $2,5 \%$.

\section{5. Qualidade sensorial dos produtos}

Analisando-se estatisticamente os dados obtidos na análise sensorial realizada na Etapa I (Tabela 15 e Figura 3), observou-se que não ocorreram diferenças significativas entre os produtos, mas houve uma tendência, quanto a aceitabilidade, pelos produtos elaborados com carne de poedeira e os óleos de milho e canola. 
Tabela 15 - Avaliação sensorial dos fiambres elaborados a partir de carne de poedeira e óleos vegetais.

\begin{tabular}{lll}
\hline & ÓLEO & CARNE \\
\cline { 2 - 2 } & Soja & Poedeira \\
& Milho & $6,03 \mathrm{a}$ \\
& Girassol & $6,48 \mathrm{a}$ \\
& Canola & $5,74 \mathrm{a}$ \\
\hline $\begin{array}{l}\text { - Médias seguidas de mesma letra minúscula (coluna) não diferem entre si pelo teste } \\
\text { t-Student. }\end{array}$
\end{tabular}

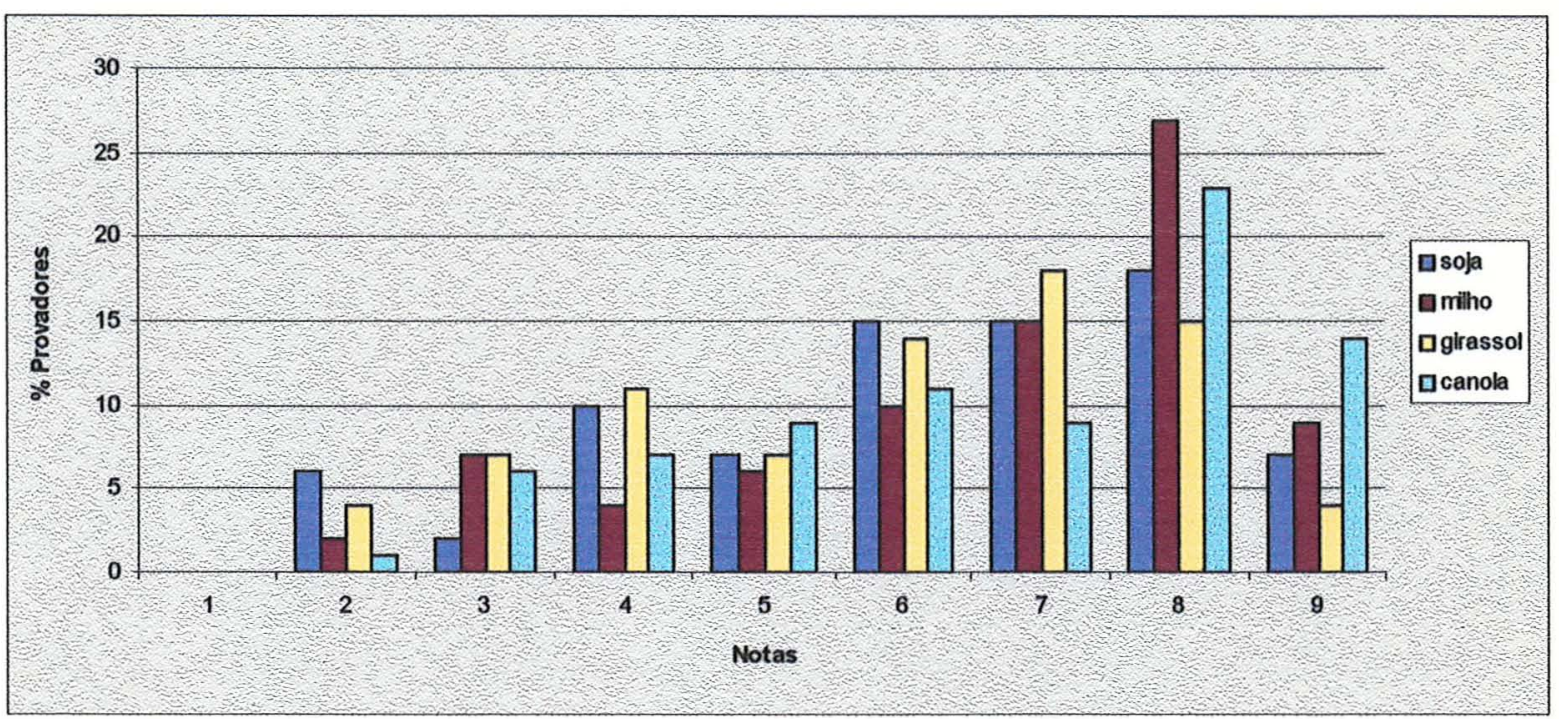

Figura 3 - Avaliação sensorial dos fiambres elaborados a partir de carne de poedeira e óleos vegetais.

Na Etapa II, os provadores avaliaram quatro produtos; dois elaborados com carne de poedeira e óleos de soja e milho e dois produtos controle, elaborados com 
carne de frango e óleos de soja e milho. Foram selecionados os óleos de soja e milho, levando-se em consideração a composição em ácidos graxos, sua disponibilidade em nosso meio e o seu preço.

De acordo com a Tabela 16 e Figura 4, observou-se, quanto ao sabor, que os produtos elaborados com carne de poedeira e óleo de soja foram superiores àqueles elaborados com carne de frango e óleo de soja e não houve diferença significativa quando elaborados com óleo de milho. Também não houve diferença entre os produtos elaborados com carne de poedeira e óleo de soja ou milho. Em relação a carne de frango, houve diferença significativa; os produtos elaborados com óleo de milho apresentaram-se superiores aos elaborados com óleo de soja.

Tabela 16 - Avaliação sensorial, quanto ao sabor, dos fiambres elaborados a partir de carne de poedeira e de frango com óleo de soja e milho.

\begin{tabular}{ccc}
\hline & \multicolumn{2}{c}{ CARNE } \\
\cline { 2 - 3 } ÓLEO & Poedeira & Frango \\
\hline Soja & $5,56 \mathrm{Aa}$ & $4,50 \mathrm{Bb}$ \\
Milho & $5,78 \mathrm{Aa}$ & $5,65 \mathrm{Aa}$ \\
\hline & & \\
\hline $\begin{array}{l}\text {-Médias seguidas de mesma letra maiúscula (linha) não diferem entre si pelo teste } \\
\text { (coluna) não diferem entre si pelo teste t-Student. }\end{array}$ \\
\hline
\end{tabular}




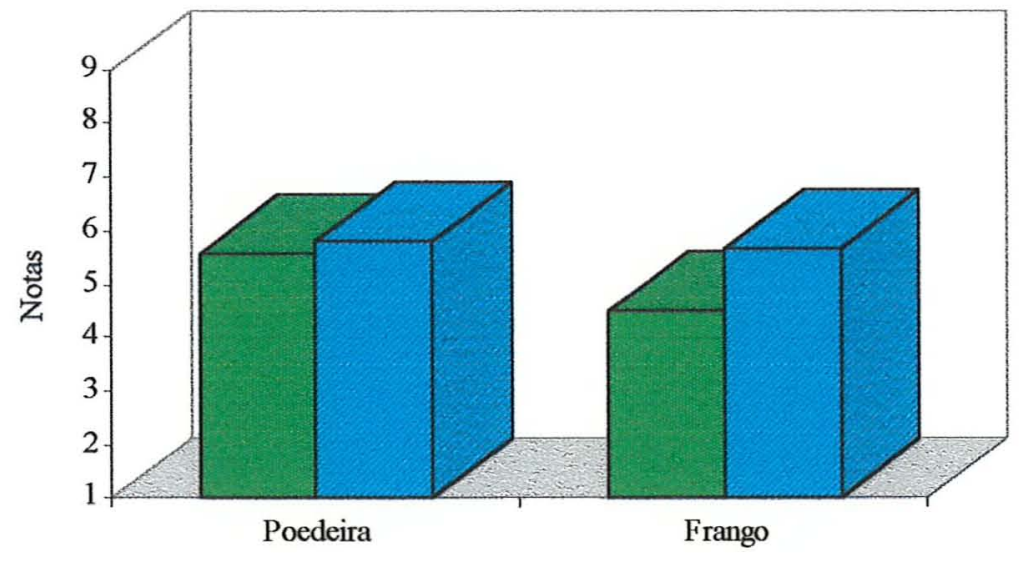

Sabor

Figura 4 - Avaliação sensorial, quanto ao sabor, dos fiambres elaborados a partir de carne de poedeira e de frango com óleo de soja e milho.

Quanto à maciez, como mostra a Tabela 17 e Figura 5, os produtos elaborados com carne de frango e óleo de soja apresentaram-se mais macios que aqueles elaborados com carne de poedeira e óleo de soja e não houve diferença significativa quando elaborados com óleo de milho. Em relação à carne de poedeira, houve diferença significativa; os produtos elaborados com óleo de milho apresentaram-se superiores aos elaborados com óleo de soja e não houve diferença significativa entre os produtos elaborados com carne de frango e óleo de soja ou milho. 
Tabela 17 - Avaliação sensorial, quanto à maciez, dos fiambres elaborados a partir de carne de poedeira e de frango com óleo de soja e milho.

\begin{tabular}{ccc}
\hline & \multicolumn{2}{c}{ CARNE } \\
\cline { 2 - 3 } ÓLEO & Poedeira & Frango \\
\hline Soja & $4,92 \mathrm{Bb}$ & $5,95 \mathrm{Aa}$ \\
Milho & $5,64 \mathrm{Aa}$ & $5,57 \mathrm{Aa}$ \\
\hline & & \\
\hline $\begin{array}{l}\text {-Médias seguidas de mesma letra maiúscula (linha) não diferem entre si pelo teste } \\
\text { (coluna) não diferem entre si pelo teste t-Student. }\end{array}$ \\
\hline
\end{tabular}

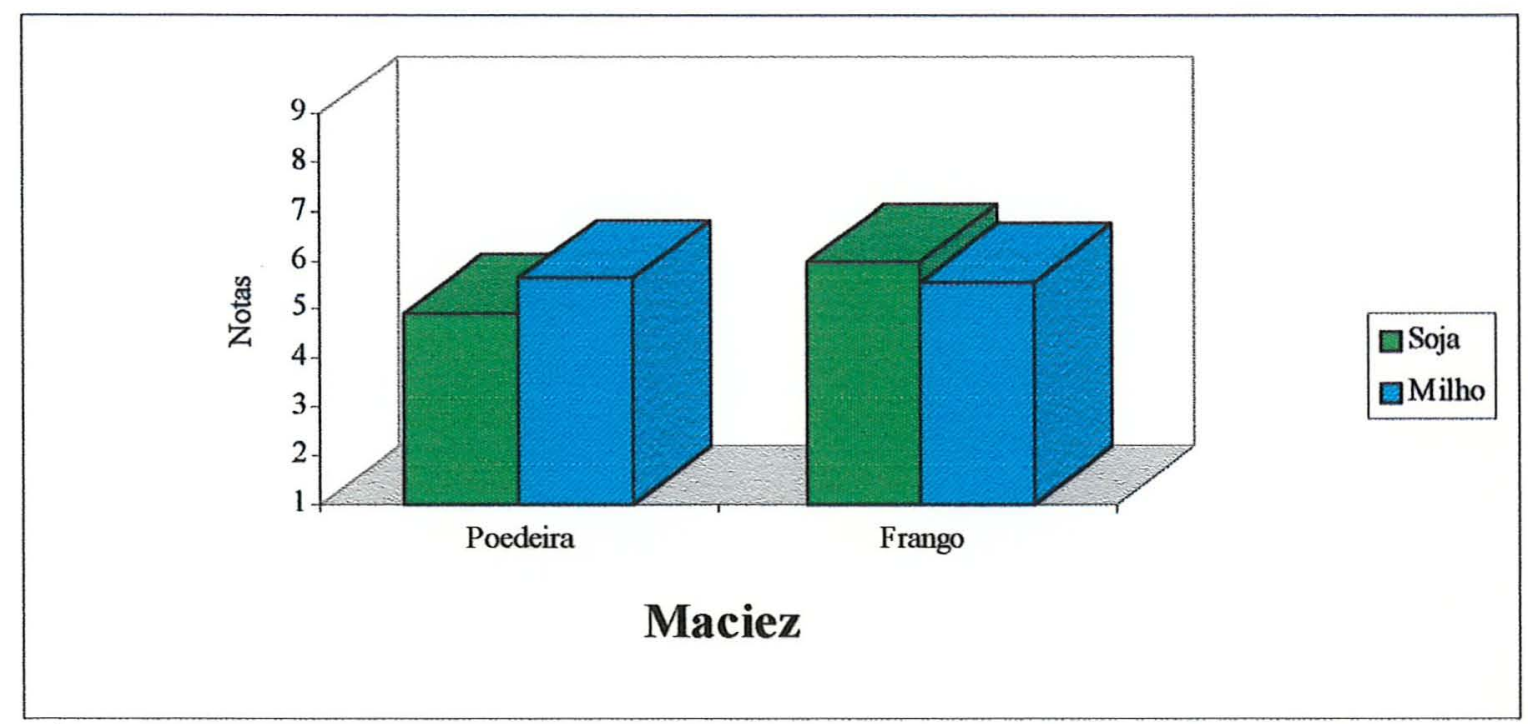

Figura 5 - Avaliação sensorial, quanto à maciez, dos fiambres elaborados a partir de carne de poedeira e de frango com óleo de soja e milho.

Não ocorreram diferenças significativas entre os tratamentos para a avaliação de suculência (Tabela 18 e Figura 6). 
Tabela 18 - Avaliação sensorial, quanto à suculência, dos fiambres elaborados a partir de carne de poedeira e de frango com óleo de soja e milho.

\begin{tabular}{ccc}
\hline & \multicolumn{2}{c}{ CARNE } \\
\cline { 2 - 3 } ÓLEO & Poedeira & Frango \\
\hline \multirow{2}{*}{ Soja } & $5,18 \mathrm{Aa}$ & $5,52 \mathrm{Aa}$ \\
Milho & $5,56 \mathrm{Aa}$ & $5,53 \mathrm{Aa}$ \\
\hline & & \\
\hline $\begin{array}{l}\text { t-Médias seguidas de mesma letra maiúscula (linha) não diferem entre si pelo teste } \\
\text { (coluna) não diferem entre si pelo teste t-Student. }\end{array}$ \\
\hline
\end{tabular}

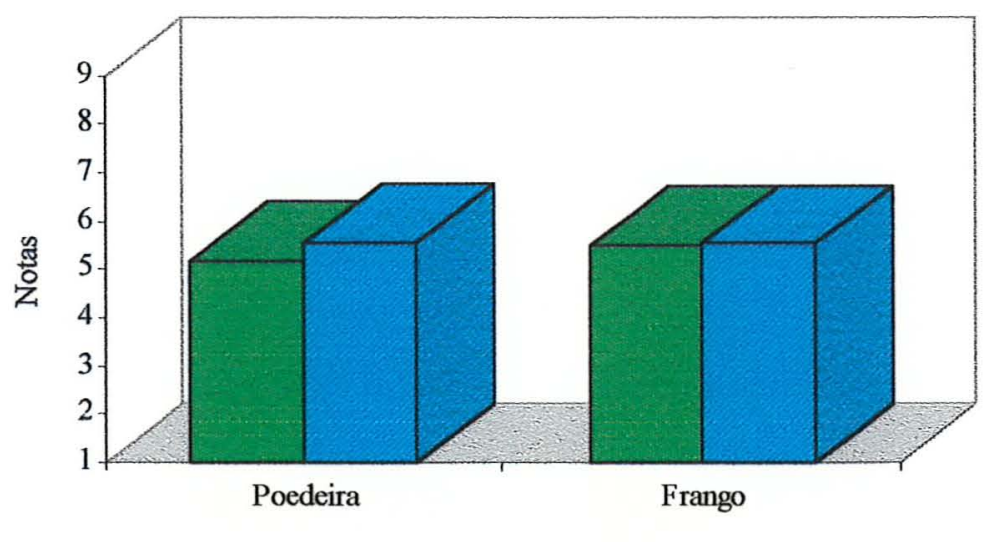

Suculência

Figura 6 - Avaliação sensorial, quanto à suculência, dos fiambres elaborados a partir de carne de poedeira e de frango com óleo de soja e milho.

Em relação à cor (Tabela 19 e Figura 7), constatou-se que os produtos 
elaborados com carne de poedeira e óleo de soja ou milho foram superiores, como era previsto, pois a carne de poedeira apresentava uma coloração mais intensa que a carne de frango.

Tabela 19 - Avaliação sensorial, quanto à cor, dos fiambres elaborados a partir de carne de poedeira e de frango com óleo de soja e milho.

\begin{tabular}{ccc}
\hline & \multicolumn{2}{c}{ CARNE } \\
\cline { 2 - 3 } ÓLEO & Poedeira & Frango \\
\hline Soja & $5,48 \mathrm{Aa}$ & $3,83 \mathrm{Ba}$ \\
Milho & $5,90 \mathrm{Aa}$ & $4,22 \mathrm{Ba}$ \\
\hline & & \\
\hline $\begin{array}{l}\text {-Médias seguidas de mesma letra maiúscula (linha) não diferem entre si pelo teste } \\
\text { (coluna) não diferem entre si pelo teste t-Student. }\end{array}$ \\
\hline
\end{tabular}

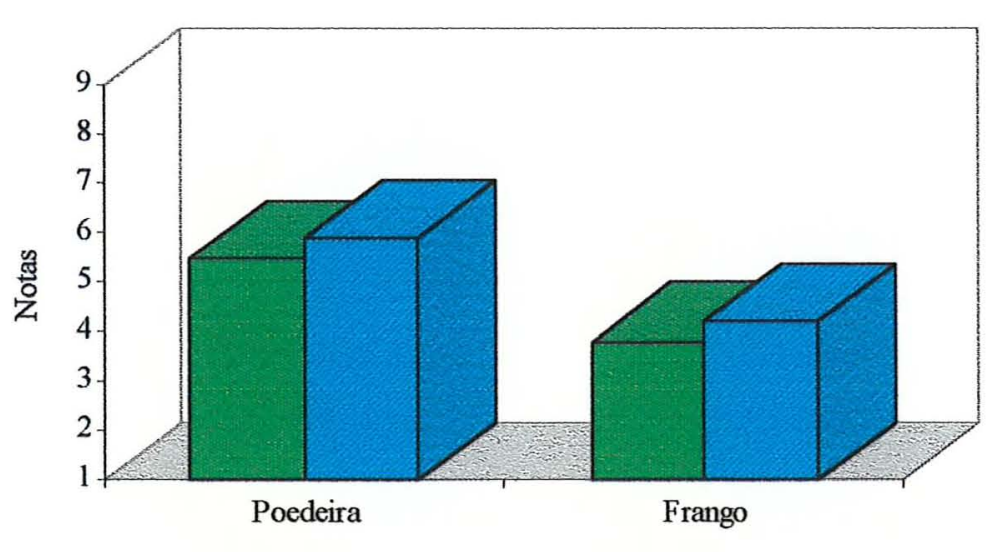

Cor

Figura 7 - Avaliação sensorial, quanto à cor, dos fiambres elaborados a partir de carne de poedeira e de frango com óleo de soja e milho. 
Quanto à qualidade global (Tabela 20 e Figura 8), houve preferência pelos produtos elaborados com carne de poedeira e óleo de soja, em relação à carne de frango. Para o óleo de milho não houve diferença significativa; em relação ao produto controle, os elaborados com óleo de milho foram os preferidos.

Tabela 20 - Avaliação sensorial, quanto à qualidade global, dos fiambres elaborados a partir de carne de poedeira e de frango com óleo de soja e milho.

\section{CARNE}

\begin{tabular}{ccc}
\cline { 2 - 3 } ÓLEO & Poedeira & Frango \\
\hline Soja & $5,65 \mathrm{Aa}$ & $4,82 \mathrm{Bb}$ \\
Milho & $5,71 \mathrm{Aa}$ & $6,09 \mathrm{Aa}$
\end{tabular}

-Médias seguidas de mesma letra maiúscula (linha) não diferem entre si pelo teste t-Student ao nível de 0,05 de probalidade. Médias seguidas de mesma letra minúscula (coluna) não diferem entre si pelo teste t-Student.

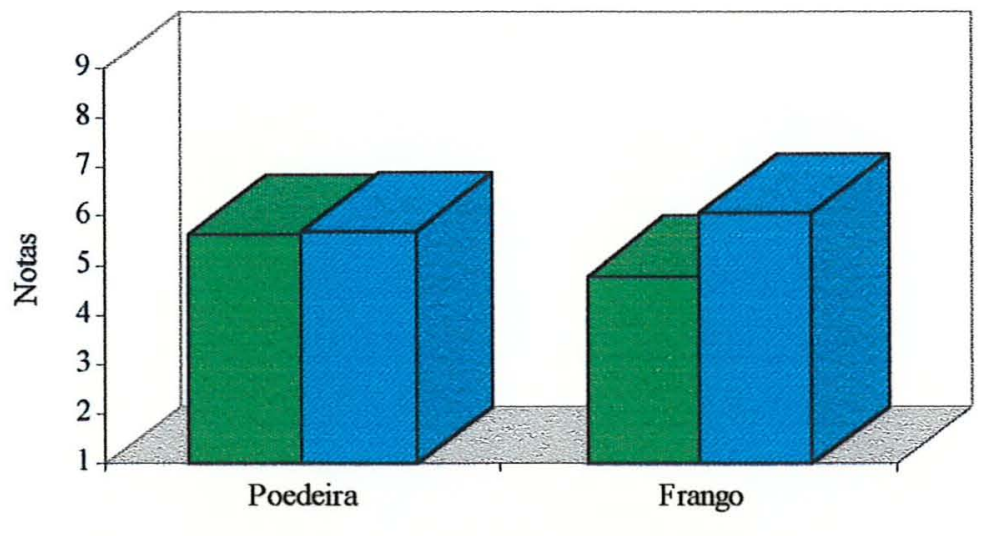

\section{Qualidade Global}

Figura 8 - Avaliação sensorial, quanto à qualidade global, dos fiambres elaborados a partir de carne de poedeira e de frango com óleo de soja e milho. 
Considerando os produtos elaborados com carne de poedeira verificou-se que, apesar de não haver diferença significativa entre os óleos de soja e milho, os provadores tenderam a preferir os produtos elaborados com o óleo de milho.

As Figuras 9 e 10 mostram os fiambres da Etapa I e II, respectivamente após o processamento térmico e cortados após o resfriamento. As diferenças de cor observadas nas fotos são devidas a iluminação não uniforme.

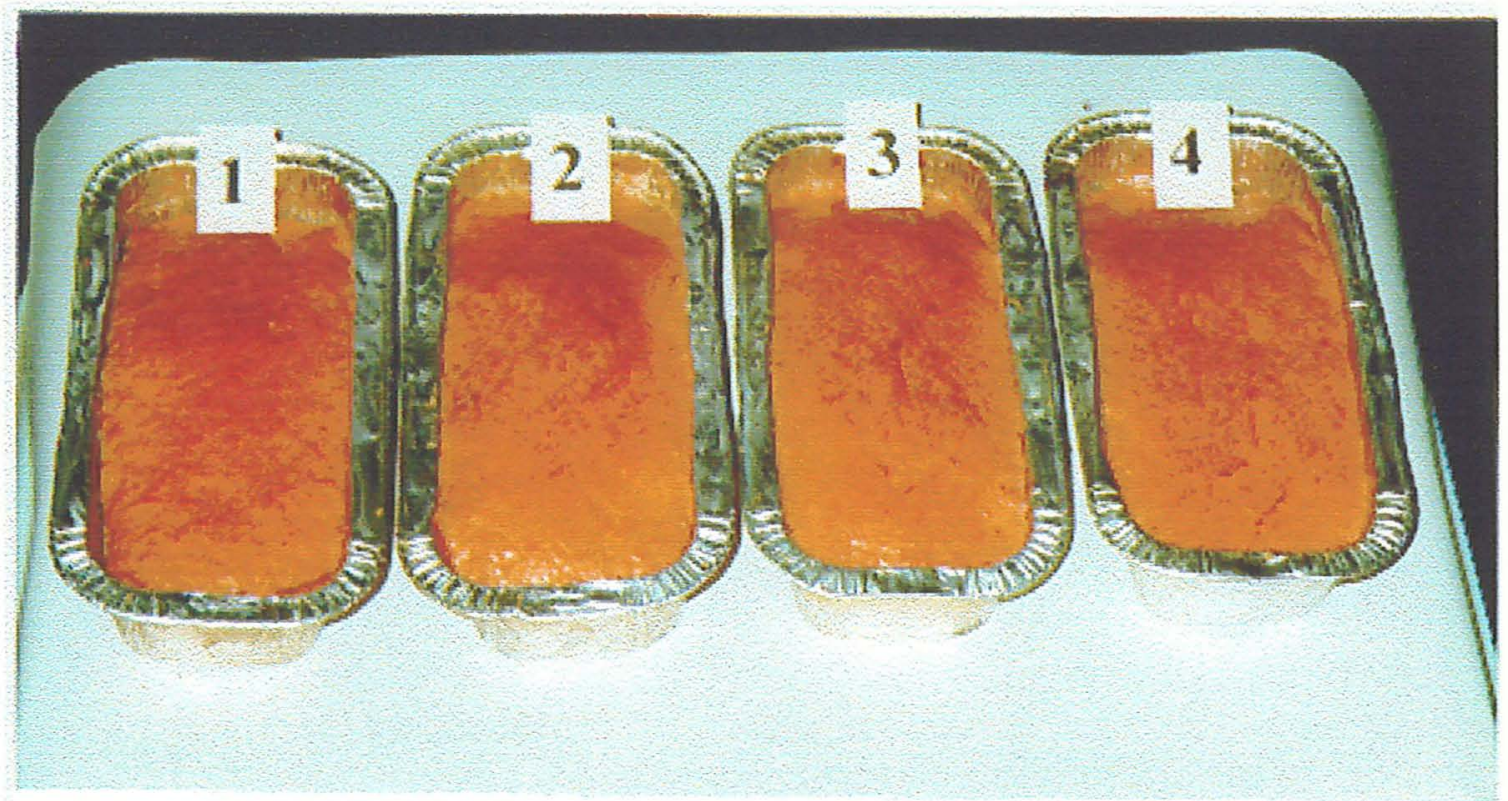

Figura 9- Fiambres de carne de poedeiras elaborados com óleo de soja (1), óleo de milho (2), óleo de girassol (3) e óleo de canola (4) (Etapa I). 


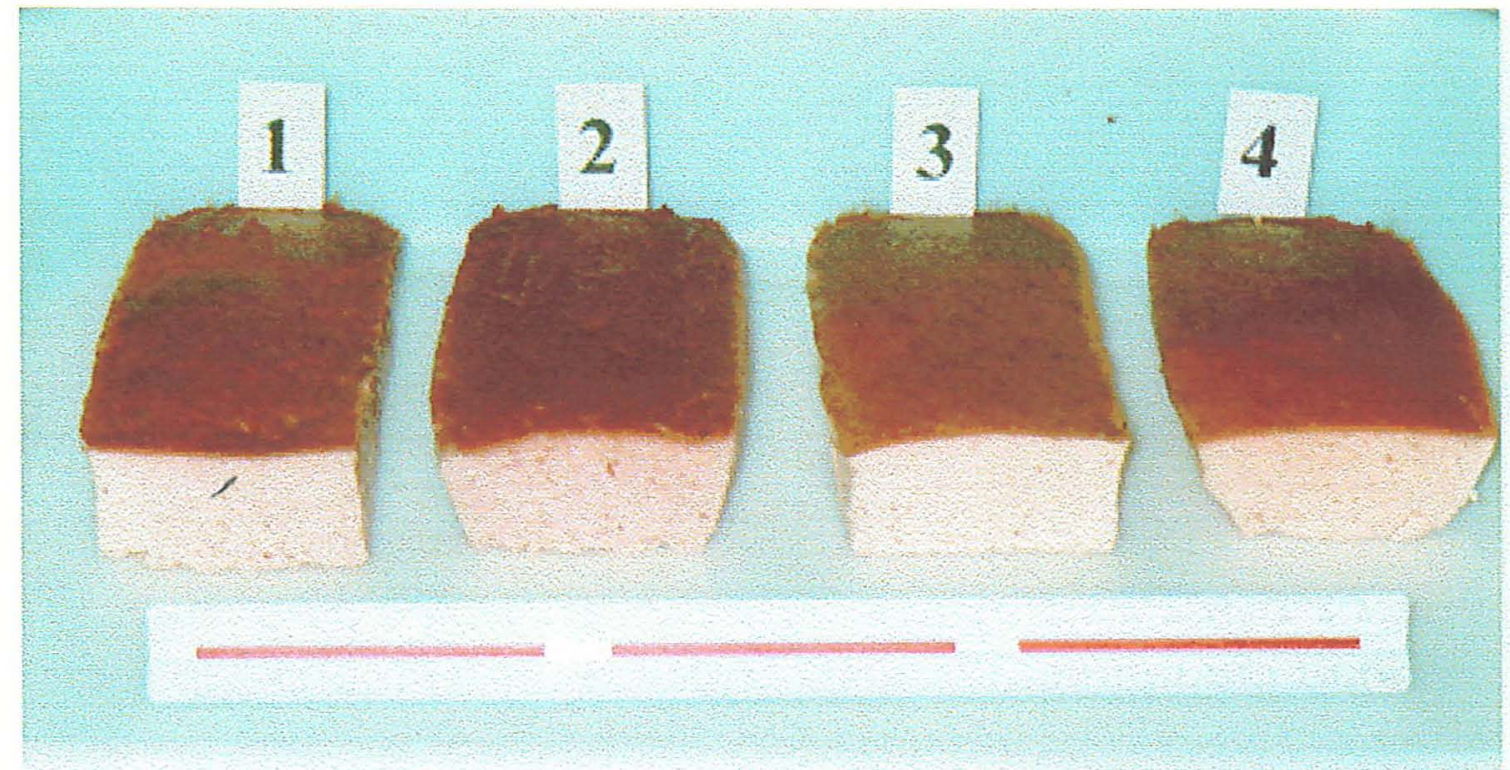

Figura 10 - Fiambres de carne de poedeiras elaborados com óleo de soja (1) e óleo de milho (2) e fiambres de carne de frangos elaborados com obleo de soja (3) e óleo de milho (4) (Etapa II). 


\section{CONCLUSÕES}

Os resultados, nas condições do presente trabalho, possibilitam as seguintes conclusões:

- Produtos de emulsão podem ser elaborados com carne de poedeiras leves e óleos vegetais.

- Óleos de soja, milho, girassol e canola podem ser utilizados na elaboração de fiambres com carne de poedeiras leves, na proporção de $12,5 \%$, pois não ocasionam instabilidade da emulsão.

- O rendimento no tratamento térmico (defumação a quente), seguido de resfriamento, para os produtos elaborados com carne de poedeira e óleos vegetais é elevado $(94,96 \%)$.

- Os rendimentos são, em média, de $34,79 \mathrm{~kg}$ de fiambre para $100 \mathrm{~kg}$ de carcaças de poedeiras (congeladas) e $113,76 \mathrm{~kg}$ de produto para $100 \mathrm{~kg}$ de carne mista.

- O fiambre elaborado com carne de poedeira e óleo de soja é mais saboroso que o elaborado com carne de frango e óleo de soja. Por outro lado, o fiambre elaborado com carne de frango e óleo de soja é mais macio, em relação à carne de galinha. A cor dos fiambres elaborados com carne de poedeira é mais atrativa que a obtida com carne de frango. Quanto à qualidade global, os produtos elaborados com carne de poedeira e óleo de soja são os preferidos, em relação à carne de frango. 


\section{REFERÊNCIAS BIBLIOGRÁFICAS}

ANUÁRIO ESTATÍSTICO DA PRODUÇÃO ANIMAL - ANUALPEC. São Paulo, 1996.

APINCO - AVICULTURA DE CORTE - BRASIL - 1996 - 15 anos de levantamento. 20p.

ARIMA, H. K.; CIPOLLI, K. M. V. A. B.; CAMARGO, G. B. F. Análise sensorial de produtos de aves. Campinas: ITAL, 1994. 43p.

ASSOCIATION OF OFFICIAL ANALYTICAL CHEMISTS - A.O.A.C. Official methods of analysis. 11.ed. Washington, 1970. 1015p.

BAKER, R. C.; DARFLER, J. M. Acceptability of frankfurters made from mechanically deboned turkey framers as affected by formulation changes. Poultry Science, v.54, n.4, p.1283-1288, 1975. 
BAKER, R. C.; DARFLER, J. M.; VADEHRA, D. V. Type and level of fat and amount of protein and their effects on the quality of chicken frankfurters. Food Technology, Chicago, v.23, n.6, p.100-103, 1969.

BAKER, R. C.; DARFLER, J. M.; VADEHRA, D. V. Effect of $\mathrm{pH}$ on the quality of chicken frankfurters. Journal of Food Science, v.35, n.5, p.693-695, 1970.

BERAQUET, N. J. Industrialização de carne de aves. In: ITAL Industrialização da carne de frango. Campinas, 1992. p.72-78.

BORTOLUZZI, R. C. Elaboração de fiambres (emulsões) com carne de frango e óleos vegetais. Piracicaba, 1993. 72p. Tese (Mestrado) Escola Superior de Agricultura "Luiz de Queiroz", Universidade de São Paulo.

BRECLAW, E. W.; DAWSON, L. E. Smoke - flavored chicken rolls. Journal of Food Science, v.35, n.4, p.379, 1970.

CANHOS, D. A. L.; DIAS, E. L. Tecnologia de carne bovina e derivados. São Paulo: Secretaria da Indústria, Comércio, Ciência e Tecnologia, 1983. 439p. 
GRANER, M. Industrialização da carne de aves: Efeito de algumas variáveis de processamento sobre propriedades fisicas, químicas e organoléticas de produto obtido com a carne de poedeiras (Gallus gallus domésticus), ao final da exploração comercial. Piracicaba, 1973. 113p. Tese (Livre - Docência). Escola Superior de Agricultura "Luiz de Queiroz", Universidade de São Paulo.

GRANER, M. Efeito de algumas variáveis de processamento sobre propriedades organolépticas, físicas e químicas de massa obtida com a carne de poedeiras. Anais da Escola Superior de Agricultura "Luiz de Queiroz", v.31, p.133- 146, 1974.

GRANER, M. Estudo e desenvolvimento de produtos à base de carne de frango. Relatório de Pesquisas. Piracicaba: FEALQ, 1985. 150p.

GRANER, M. Rendimento no corte e na desossa manual parcial de carcaças resfriadas comerciais de frango (Gallus gallus). Anais da Escola Superior de Agricultura "Luiz de Queiroz", v.44, p.1219$1232,1987 a$. 
GRANER, M. Elaboração de fiambre com emulsão de carne mista e gordura de frango (Gallus gallus), sem e com pele. Anais da Escola Superior de Agricultura "Luiz de Queiroz", v.44, p.273-297, $1987 b$.

GRANER, M. Elaboração de fiambres com as carnes branca e escura de frango. Scientia Agrícola, v.49, n.1, p.167-172, 1992.

GUIA AVES \& OVOS 96 - Aves e Ovos - Associação Paulista de Avicultura, v.12, n.4, p.50, fev. 1996.

HANSEN, L. J. Emulsion formation in finely comminuted sausage. Food Technology. v.14, p.565-569, 1960.

HELMER, R. L.; SAFFLE, R. L. Effect of chopping temperature on the stability of sausage emulsions. Food Technology. v.17, p.1195-1197, 1963.

HUDSPETH, J. P.; MAY, K. N. A study of the emulsifying capacity of salt soluble proteins of poultry meat. I. Light and dark meat tissues of turkeys, hens and broilers, and dark meat tissues of ducks. Food Technology. v.21, p.1141, 1967. 
JACOBS, M. B. The chemical analysis of food and food products. Princeton: Van Nostrand, 1958. 2580p.

JONES, K. W.; MANDIGO, R. W. Effects of chopping temperature on the microstructure of meat emulsions. Journal of Food Science, v.47, n.12, p.1930-1935, 1982.

JUDGE, M. D.; ABERLE, E. D.; FORREST, J. C. Principles of meat science. 2.ed. San Francisco: Freeman, 1989. 417p.

KELLEY, D. C.; GUERRANT, R. E.; MACKINTOSH, D. L. A study of methods of testing and sampling for the determination of fat content of ground meat. Food Technology, Chicago, v.8, p.273, 1954.

KONDAIAH, N.; PANDA, B.; ANJANEYULU, A. S. R. Meat yields and quality characteristics of meat from spent hens of White Leghorn and Rhode Island Red breeds. Journal of Food Science and Technology, v.24, n.2, p.78-81, 1987.

LYONS, J. J.; VANDEPOPULIERE, J. M. Spent Leghorn Hens Converted Into a Feedstuff. Journal Applied Poultry Research, v.5, p.18-25, 1996. 
MARQUEZ, E. J.; AHMED, E. M.; WEST, R. L.; JOHNSON, D. D. Emulsion stability and sensory quality of beef frankfurters produced at different fat or peanut oil levels. Journal of Food Science, v.54, n.4, p.867-870, July/ Aug. 1989.

MAURER, A. J.; BAKER, R. C. The relation-ship between collagen content and emulsifying capacity of poultry meat. Poultry Science. v.45, p.1317-1321, 1966.

MAURER, A. J.; BAKER, R. C.; VADEHRA, D. V. Kind and concentratrion of soluble protein extract and their effect on the emulsifying capacity of poultry meat. Food Technology. v.23, p.177$179,1969$.

MOREIRA, R. T. Efeito da proteína texturizada de soja na qualidade de emulsão de carne de frango, elaborada com óleos vegetais. Piracicaba, 1994. 85p. Tese (Mestrado). Escola Superior de Agricultura “Luiz de Queiroz”, Universidade de São Paulo.

MORI, E. E. M. Métodos sensoriais e físicos para avaliação de alimentos e bebidas: princípios e aplicação. Campinas: Ital, 1982. $50 \mathrm{p}$. 
MURAKAMI, A. E.; NERILO, N.; FURLAN, A. C.; SCAPINELLO, C.; BARBOSA, M. J. B.; CARDOSO, A. Desempenho, rendimento de carcaça, cortes e desossa de três linhagens comerciais de frango de corte. In: CONFERÊNCIA APINCO 1995 DE CIÊNCIA E TECNOLOGIA AVÍCOLAS, 1995. Curitiba. Trabalhos de pesquisa Campinas: FACTA, 1995. p.279-280.

OLIVEIRA, L. C. Novos critérios na inspeção industrial e sanitária de aves. In: CONFERÊNCIA APINCO 1995 DE CIÊNCIA E TECNOLOGIA AVÍCOLAS, 1995, Curitiba. [ANAIS] Campinas: FACTA, 1995. p.119-134.

PARK, J., RHEE, K. S.; ZIPRIN, Y. A. Low-fat frankfurters with elevated levels of water and oleic acid. Journal of Food Science, Chicago, v.3, n.55, p.781-784, 1990.

PARK, J.; RHEE, K. S.; KEETON, J. T.; RHEE, K. C. Properties of low fat frankfurters containg monounsaturated and omega 3 polyunisaturated oils. Journal of Food Science, Chicago, v.3, n.54, p.500-504, 1989. 
PIMENTEL - GOMES, F. Curso de estatística experimental. 10.ed. São Paulo: Nobel, 1987. 430p.

PRIBIS, V.; VUJKOVIC, J.; REDE, R.; POPOVIC, M. The influence of skin emulsions and mechanically deboned meat addition on properties of poultry meat cooked sausages. Tehnologija - Mesa, v.34, n.2 / 3, p.86-88, 1993.

RIBEIRO, D. F. Influência do manejo do pré-abate e das operações de abate na qualidade e rendimento das carcaças. Revista Nacional da Carne, v.19, n.223, p.38-46, set. 1995.

ROÇA, R. O. Desenvolvimento de fiambres com carne de frango. Campinas, 1986. 183p. Tese (Mestrado) - Faculdade de Engenharia de Alimentos, Universidade de Campinas.

ROÇA, R. O.; SERRANO, A. de M.; BONASSI, I. A. Influência da utilização da proteína texturizada de soja nas características sensoriais, químicas e funcionais e de processamento do fiambre de frango. Pesquisa Agropecuária Brasileira, v.29, n.11, p.1763-1768, nov. 1994. EMBRAPA. 
SANZ EGAÑA, C. S. Enciclopedia de la carne. Madrid: Espasa Calpe, 1967. 639p.

SCHNEIDER, I. S. Processamento industrial de aves e seus subprodutos. São Paulo: Ed. Brasileira de Agricultura, 1973. 80p.

SCHNEIDER, I. S.; SANTOS, J. C.; SERRANO, A. de M. Processamento de carne de ave adicionada de farinha texturizada de soja I. Embutidos defumados. Boletim da Sociedade Brasileira de Ciência e Tecnologia de Alimentos, v.15, n.1, p.47-65, jan./mar, 1981.

SWIFT, C. E.; LOCKETT, C.; FRYAR, A. J. Comminuted meat emulsions - the capacity of meats for emulsifying fats. Food Technology. v.15, p.468-473, 1961.

XIONG, Y. L.; BLANCHARD, S. P.; MEANS, W. J. Properties of broiler myofibril gels containing emulsified lipids. Poultry Science, v.71, n.9, p.1548-1555, 1992.

YANG, S. C.; CHEN, T. C. Effect of sodium nitrite concentration and curing time on the color development of chicken ham. Food Science, v.15, n.3, p.254-262, 1988. 
APÊNDICE 1 


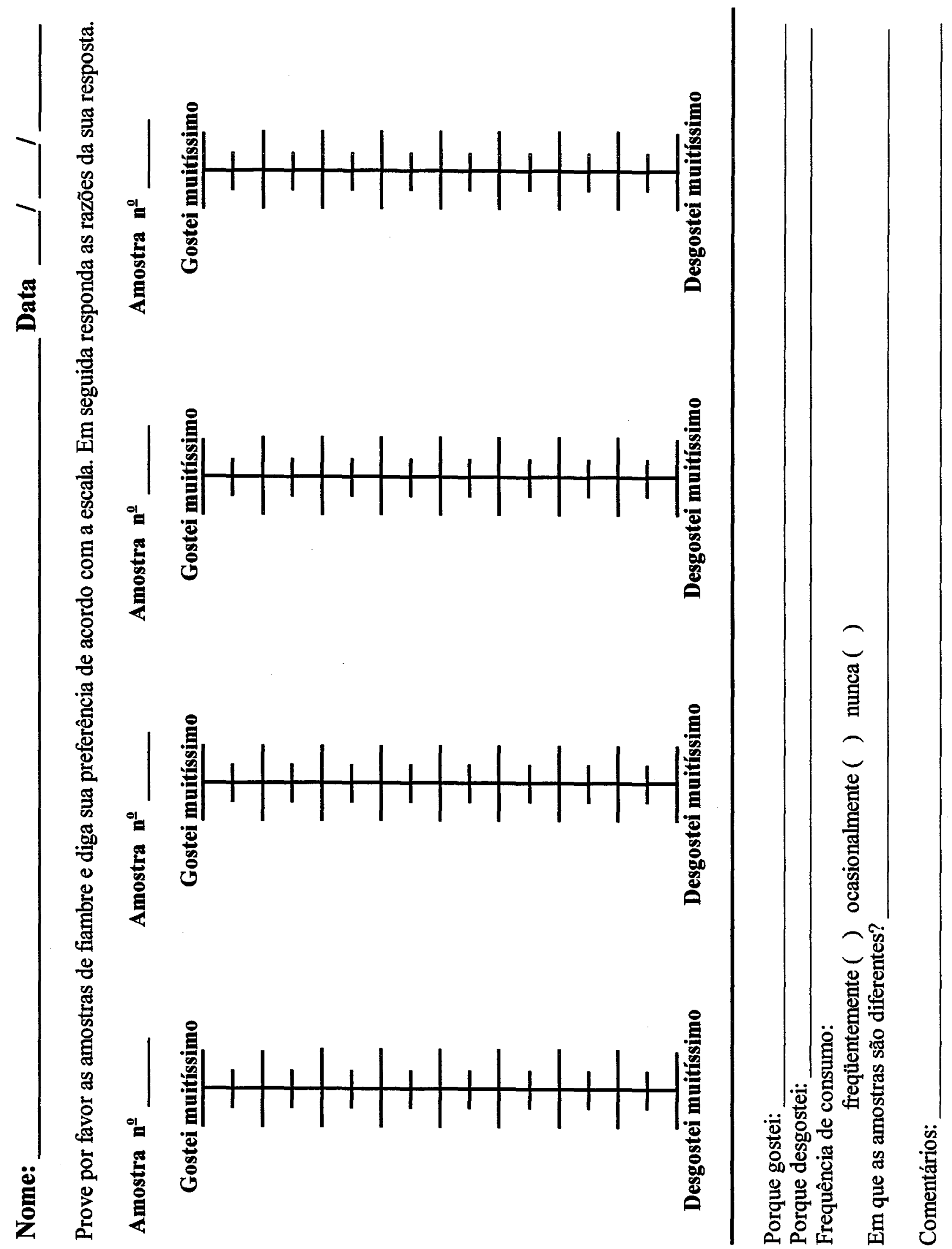


APÊNDICE 2 
